\title{
LA JUSTICIA TRANSICIONAL: ¿LA RENUNCIA DE LO IRRENUNCIABLE?
}

\author{
Nuria Belloso Martin ${ }^{1}$
}

\section{Resumen}

La justicia transicional no suele gozar de aceptación por parte de las víctimas de violaciones sistemáticas de derechos humanos porque suelen asimilarla a impunidad o a penas simbólicas por parte de los victimarios. Por ello, se resisten a renunciar a lo irrenunciable, como es la justicia. El derecho a la reparación integral implica que los juicios se ejercen con control democrático y que nadie está por encima de la ley. En este procesos de paz sean transparentes y con control democrático. En este estudio se analizará el concepto, fases y principios de la justicia transicional. Estos planteamientos permitirán hacer una relectura de los diversos procesos de justicia transicional. Se prestará especial atención al proceso de paz en Brasil y al análisis del Acuerdo de paz en Colombia -que acaba ser rechazado por los ciudadanos colombianos en referéndum-. Este trabajo pretende dar respuesta al reto de buscar un equilibro entre el derecho a la verdad (historia - memoria, con el consiguiente derecho a saber sobre las personas asesinadas o desparecidas) y el perdón y la conciliación. El derecho a la justicia se erige con la piedra angular de estos procesos. No puede haber paz si se sacrifica la justicia.

Palabras llave: Justicia Transicional; Memoria; Olvido; Perdón; Conciliación.

\section{JUSTICIA TRANSICIONAL: CONCEPTO Y FASES HISTÓRICAS}

Los procesos de negociación o acuerdos de paz han sido frecuentes tanto en el siglo XX como en lo que llevamos de siglo XXI. El cómo castigar las violaciones de derechos humanos y atrocidades se liga a la instauración de la paz y de la democracia. En el Derecho público contemporáneo se ha configurado una institución clave como es el llamado "derecho de las víctimas a la justicia" en su triple acepción de derecho a la verdad y a la memoria, derecho al castigo de los responsables de los abusos y derecho a la reparación de los damnificados. Justicia, verdad y reparación se configuran como una égide que permite aportar a los procesos de justicia transicional el mínimum de moralidad imprescindible para dotar de legitimidad a estos procesos.

La versión más autorizada de esta vieja y nueva garantía en la legalidad internacional se encuentra hoy en la Resolución 60/147, de 16 de diciembre de 2005, por medio de la cual la Asamblea General de las Naciones Unidas aprobó el texto final de la doctrina oficial de la organización mundial en la materia. ${ }^{2}$ Según esta Resolución,

\footnotetext{
${ }^{1}$ Profesora Titular de Filosofía del Derecho en la Facultad de Derecho de la Universidad de Burgos (España). Coordinadora del Programa de Doctorado del Departamento de Derecho Público “Sociedad plural y nuevos retos del Derecho”. Directora del Curso de Especialista Universitario en Mediación Familiar. E-mail: nubelloso@gmail.com

${ }^{2}$ Aparece bajo el título de "Principios y directrices básicos sobre el derecho de las víctimas de violaciones manifiestas de las normas internacionales de derechos humanos y de violaciones graves del derecho internacional humanitario a interponer recursos y vol.10, nº. 01, Rio de Janeiro, 2017.pp.333-364 
el Estado debe garantizar el derecho de las víctimas a la justicia, que consta de tres elementos fundamentales: el acceso igual y efectivo a la justicia; la reparación adecuada, efectiva y rápida del daño sufrido; y el acceso a información pertinente sobre las violaciones y los mecanismos de reparación. Como puede observarse, justicia y reparación siguen siendo las claves sobre las que gravitan las acciones que el Estado debe llevar a cabo para que las víctimas que claman justicia obtengan su reparación.

La justicia transicional tiene ante sí el difícil reto, ya no sólo de articular los mecanismos para llegar a una reconciliación jurídico-política sino principalmente, moral, promoviendo la reconciliación entre los ofensores, las víctimas y las comunidades locales. Mediante el análisis del concepto, fases históricas y fundamentos de la justicia transicional, revisaremos algunos de los aspectos principales de los procesos de justicia transicional en Brasil y en Colombia en las páginas que siguen.

La justicia transicional es una respuesta a las violaciones sistemáticas o generalizadas a los derechos humanos. Su objetivo es reconocer a las víctimas y promover iniciativas de paz, reconciliación y democracia. ${ }^{3}$ Abarca un conjunto de mecanismos que se utilizan en condiciones y circunstancias extraordinarias y que desembocan en unas políticas de transición. Por tanto, no es propiamente un tipo de justicia sino que constituye una manera de abordar la justicia. ${ }^{4}$ En la justicia transicional tanto el Derecho como la política juegan un papel esencial. El resultado de esta interrelación resulta propicio para buscar escenarios facilitadores de la convivencia y la democracia en contextos de postconflicto, en los que pasado y futuro dejen de subordinarse uno al otro. El holocausto judío en Europa, los desaparecidos en Argentina y en Chile, las víctimas de las guerrillas de las FARC en Colombia, entre otros, constituyen escenarios propicios para analizar las posibilidades de sustentación de la justicia transicional.

obtener reparaciones". http://www.ohchr.org/SP/ProfessionalInterest/Pages/RemedyAndReparation.aspx. (Acceso el 15.03.2016).

3"Qué es la justicia transicional". Centro Internacional para la Justicia Transicional. https://www.ictj.org/sites/default/files/ICTJGlobal-Transitional-Justice-2009-Spanish.pdf (Acceso el 15.02.2015).

${ }^{4}$ Como destaca Falcón y Tella (2014, pp.17-18), en la Biblia podemos encontrar numerosos pasajes sobre la justicia. Así, en el Génesis 3: 1-24, se describe la expulsión de Adán y Eva del paraíso, por haber infringido la orden del Creador de no comer del fruto del Árbol del Bien y del Mal. También en el Génesis 18:20-33 y 19:1-28 se describe la destrucción de Sodoma y Gomorra, argumentando cuál ha de ser el número de hombres justos para impedirla y si bastaría con un solo hombre justo en ellas para que esas ciudades no fuesen destruidas. En el Levítico 24: 17-22 se encuentra una referencia a la ley del talión: "ojo por ojo y diente por diente”. Las Sagradas Escrituras admiten en varios pasajes el ius puniendi, como cuando en el Capítulo 22 del Éxodo, el cual ordena la pena de muerte a los adoradores de ídolos. Es decir, cabe extraer la conclusión de que el Antiguo Testamento no reprueba la justicia retributiva. Sin embargo, en el Nuevo Testamento está más presente la idea de perdón. Baste recordar el pasaje de Lucas 15: 11-32, en la parábola del hijo pródigo, que tras haberse marchado de su casa y haber malversado los bienes de su padre, vuelve junto a él quien lo acoge y lo perdona, porque era un hijo que estaba perdido y lo ha recuperado, frente al escepticismo del otro hijo que siempre había permanecido junto a su padre. Por tanto, parece haber una oposición entre unos textos favorables al ius puniendiy otros textos partidarios de una misericordia sin límites. Berinstain (1982, p.35), intentado aclarar esta posición, sostiene que cuando el Nuevo Testamento prohíbe la retribución se refiere a los individuos en cuanto personas particulares. En cambio, cuando se trata de relaciones sociales, admite con claridad la autoridad punitiva. Además, la exigencia bíblica del perdón no excluye una sanción punitiva. El perdón destruye la exigencia punitiva de la culpa pero no la exigencia reequilibradora de la pena. El Estado puede y debe reconocer estas exigencias de la pena. 
En este tipo de justicia se acaba confundiendo el perdón con temas tangenciales pero de ningún modo sinónimos: la disculpa, el pesar, la amnistía, la conciliación, la prescripción, entre otros, que corresponden unos al ámbito del derecho penal y otros, al de la moralidad y la religión (RODRÍGUEZ, 2010, p. 1). El perdón no es un concepto jurídico como tal, el Derecho no está pensado para conceder el perdón sino para prevenir conductas dañosas y, si se llevan a cabo, castigar y punir. Perdón y conciliación no han sido nunca los fines del Derecho. En estos casos, ¿quién debe otorgar el perdón?, ¿los políticos de turno?, ¿las víctimas? Y la memoria y el castigo, ¿cómo pueden conciliarse con el perdón y el olvido? Las víctimas, en aras de la construcción de una convivencia pacífica, ¿deben ser quienes olviden, quienes acepten la mano de la reconciliación que se les tiende? Y esto, ¿sin que haya reparación?, ¿isin que haya habido una previa retribución mediante el castigo a los culpables? Como se pregunta Rodríguez Montenegro, “¿Cuánto perdón y cuánto olvido son necesarios para la reconciliación y cuánta justicia, verdad y reparación le son funcionales?"5.

Esta presentación de la justicia transicional nos permite entender un concepto que, desde su propia terminología, resulta ambiguo. Justicia transicional o justicia transaccional, como otros la denominan, hace alusión precisamente a un periodo de transición en el que se produce una transacción, un acuerdo, entre los grupos o comunidades implicadas. ${ }^{6}$ Para algunos autores se configura como una nueva categoría de justicia. Sin embargo, ni su configuración y, menos aún su aceptación, es fácil. Las Madres de la Plaza de Mayo en Buenos Aires, desde los años setenta hasta nuestros días, siguen esgrimiendo sus pancartas con la frase: "ni perdón ni olvido" y seguimos asistiendo a emocionados encuentros de las ahora abuelas con hijos y nietos reencontrados. La justicia que reclaman no es la vinculada al perdón ni al olvido porque no pueden olvidar los años de sufrimiento y desesperación por no conocer el paradero de sus hijos. La justicia que claman es la del castigo de los culpables. ¿Cómo defender entonces una justicia transicional?

Como señala Rodríguez (2010), en la evolución de la justicia transicional pueden distinguirse tres fases históricas diferentes. "La primera, que surge en 1945 y corresponde a los juicios de la posguerra. Se caracteriza por el triunfo de la justicia transicional dentro del esquema del Derecho Internacional a partir de la colaboración entre Estados, la realización de procesos por crímenes de guerra y la imposición de sanciones a los países vencidos" (RODRÍGUEZ, 2010, p. 2). El enjuiciamiento de los hechos se sustrae al Estado nacional y se deposita en

\footnotetext{
${ }^{5}$ Rodríguez Montenegro (2011, p. 53), define la justicia transicional como "una concepción de justicia empleada en contextos de cambio político tales como la salida de un régimen represor o la finalización de un conflicto armado, que incluye una variedad de respuestas legales con miras al tratamiento de los delitos cometidos en tiempos de dictadura o guerra". El sociólogo suizo, Jon Elster (2006, p.15) afirma que "la justicia transicional está compuesta de los procesos penales, de depuración y de reparación que tienen lugar después de la transición de un régimen político a otro". Configura lo que denomina "la ley de la justicia transicional", que "la intensidad de la demanda de retribución disminuye con el intervalo de tiempo entre las atrocidades y la transición, y entre la transición y los procesos judiciales". Por su parte, el pensador estadounidense Michael Walzer, utiliza la fórmula latina jus post bellum [el derecho, o la justicia, tras la guerra] para aludir a la misma cuestión, a la cual considera tributaria de la doctrina de la guerra justa. (WALZER, 2004, pp.18,169,170,172).
} 
instancias supranacionales. La principal novedad radica, como sucedió en Alemania y los juicios de Nüremberg ${ }^{7}$, en que se desplaza la potestad del enjuiciamiento del Estado nacional a los Tribunales Internacionales y, además, se extienden las responsabilidades por los crímenes del Estado alemán, como colectivo, a los individuos concretos. Se parte de un esquema de derechos universales y se justifica y se legitima la intervención de los aliados en la guerra. Es pues una justicia transicional cuyas bases son sentadas por los vencedores en nombre de un ideal de justicia universal que reconoce en el castigo de los violadores de derechos humanos un valor abstracto exigible sin restricciones (RODRÍGUEZ MONTENEGRO, 2011, p. 53).

La segunda fase de la justicia transicional se produce tras el colapso de la Unión Soviética y los procesos simultáneos de democratización en Europa del Este, África, Centro y Suramérica, a finales de los ochenta, cuando caen los regímenes autoritarios existentes que, hasta ese momento, habían estado alimentados por el bloque comunista (Ibíd.). La justicia transicional tiene como principal función la reconstrucción nacional en el marco de un discurso que destaca las virtudes de la democracia y el Estado de Derecho (RODRÍGUEZ MONTENEGRO, 2011 , p. 54). Por ello, la discusión se centra más en lo local, es decir, en cómo "los nuevos gobiernos democráticos restaurarán la paz nacional, someterán a los culpables de crímenes durante los regímenes anteriores y avanzarán en la construcción de una sociedad incluyente y libre de violaciones a los Derechos Humanos" (Rodríguez, 2010, p. 3). La comunidad internacional tiene un papel mucho más restringido que en la primera fase, sin participar apenas en los procesos de enjuiciamiento y limitándose a acompañar y observar estos procesos. Así, en el caso argentino, desde su etapa inicial, se puso de manifiesto la imposibilidad de realizar enjuiciamientos al estilo de Nüremberg. Se revelaron las dificultades para conciliar el difícil equilibrio entre perdón-castigo-olvido y memoria-verdad-justicia. Como apunta Rodríguez (2010, p.4), se sacaron a la luz "dilemas del tipo 'castigo versus amnistía' y 'olvido versus memoria', entre otros".

La tercera fase de la justicia transicional está asociada a un momento en que, aun viviendo las sociedades un tiempo de paz, sin embargo son frecuentes los conflictos que acaban prácticamente normalizando un derecho de la violencia. La Corte Penal Internacional (CPI), creada en 1998, representa el símbolo más reconocido de esta última fase al constituirse como una instancia permanente para juzgar a "los responsables de crímenes de guerra, genocidio y crímenes de lesa humanidad como la esclavitud, el apartheid, el exterminio, los asesinatos, las desapariciones forzadas, las torturas, los secuestros, la agresión y el terrorismo" (RODRíGUEZ, 2010, p. 4). Aunque los fundamentos de la CPI pueden encontrarse en los Juicios de Nüremberg y Tokio (1945-1946), la implementación de un tribunal permanente de justicia en materia criminal solo se lleva a cabo con posterioridad “a los genocidios en Yugoslavia (1991-1995) y Rwanda (1994). Su suscripción definitiva tiene lugar en Roma en

\footnotetext{
${ }^{6}$ Garapon (2014, p. 24) opta por el término justicia reconstitutiva porque pretende superar la dimensión exclusivamente instrumental que se da a la justicia transicional y restituirle su papel político.

${ }^{7}$ Cf. Pérez Triviño (2007).
} 
el marco de la Conferencia Diplomática de Plenipotenciarios de las Naciones Unidas sobre el establecimiento de una Corte Penal Internacional, el 17 de julio de 1998 (CPI, 1988)” (RODRÍGUEZ, 2011, p. 54)8.

Si en sus dos primeras fases, la justicia transicional era un modelo excepcional y extraordinario, propio de la posguerra, del post- conflicto y de la post- dictadura, en esta su última etapa se ha generalizado dado que los factores que lo provocan, tales como guerra en tiempos de paz, fragmentación política, debilidad de los Estados, guerras por los recursos, se han convertido en una constante (Ibíd.).

De esta tercera fase cabe deducir que la justicia transicional implica un alto grado de politización del derecho a la vez que da lugar a una mutación de los estándares del Estado de Derecho, que aparecen ahora más cercanos al derecho de guerra. Siguiendo los parámetros de este modelo, "la comunidad internacional puede hacer responsable a los líderes de un régimen y condenar los hechos violatorios de los Derechos Humanos, trastocando la relación tradicional entre ciudadano y Estado-nacional" (RODRÍGUEZ, 2010, p. 4). Los resultados son ambivalentes ya que, por un lado, la extensión del Derecho Internacional Humanitario pretende proteger a las víctimas con independencia de los regímenes pero, por otro, puede llegar a justificar el inicio de una guerra por razones humanitarias (Ibíd.) $)^{9}$. Cabe citar casos recientes tales como las intervenciones de la Organización del Tratado del Atlántico Norte (OTAN) en Kosovo y Afganistán, ejemplos de cómo el Derecho Internacional Humanitario (DIH) se ha convertido en una base legítima para la intervención armada en nombre de la paz. Otro caso es el de la invasión en Irak, arguyendo la "autodefensa preventiva" (del concepto de guerra justa de los clásicos, apoyada en la legítima defensa, se derivó a la guerra preventiva, apoyada en la legítima defensa preventiva, en el ataque para prevenir que ese ataque se pueda llegar a producir efectivamente) ${ }^{10}$. Todo ello dio lugar a una difícil distinción entre la guerra y la paz.

En el presente estudio, a la vista del carácter más internacionalista de derechos humanos de la primera etapa y dado el matiz marcadamente político de esta tercera fase, nos vamos a centrar en la segunda fase, porque entendemos que es la que permite diseccionar con más nitidez los fundamentos y límites de la justicia transicional desde una perspectiva iusfilosófica. Por ello, nos adherimos a la definición de la justicia transicional como "una respuesta multifacética para abordar violaciones sistemáticas o masivas de los derechos humanos que no pueden ser enfrentadas por mecanismos ordinarios" (GONZÁLEZ; HOWARD, 2013, p. 1).

\footnotetext{
${ }^{8}$ El texto del Estatuto de Roma que se distribuyó como documento A/CONF.183/9, de 17 de julio de 1998, enmendado por los procès-verbaux de 10 de noviembre de 1998, 12 de julio de 1999, 30 de noviembre de 1999, 8 de mayo de 2000, 17 de enero de 2001 y 16 de enero de 2002. El Estatuto entró en vigor el 1de julio de 2002. Puede consultarse en: <http://www.un.org/spanish/law/icc/statute/spanish/rome_statute\%28s\%29.pdf> (Acceso el 02-04-2015).

${ }^{9}$ Cf.Arcos Ramírez (2002).

${ }^{10}$ Cf. Ripol (2004, pp. 141-164).
} 


\section{PRINCIPIOS DE LA JUSTICIA TRANSICIONAL}

La justicia transicional se apoya en diversos elementos tales como: 1) la satisfacción de la justicia; 2) el derecho a la memoria histórica y a la verdad; 3) la satisfacción del derecho a la reparación de las víctimas; 4) la adopción de reformas institucionales y otras garantías de no repetición. Como un estudio de los cuatro principios excedería los marcos de este estudio, nos vamos a centrar en los tres primeros. Completaremos el análisis de estos tres principios con la reflexión de si el perdón resulta imprescindible en los procesos de justicia transicional.

\section{El derecho a la justicia}

La tipología de la justicia es amplia: desde las clásicas justicia distributiva, justicia retributiva, justicia conmutativa o sinalagmática, justicia correctiva, reparadora o restaurativa, hasta llegar a la justicia transicional. La justicia se entiende como: "virtud política que se predica de las sociedades, relaciones o decisiones bien ordenadas o proporcionadas; y como servicio público de solución de conflictos y asignación de recursos escasos o disputados mediante la interpretación razonada y razonable de ley por los jueces y el tribunal del Estado". (VALENCIA VILLA, 2003). La realización efectiva del derecho a la justicia en el marco de los procesos de transición supone la construcción y/o el fortalecimiento de escenarios formales para esclarecer la verdad y para definir las formas de la reparación. Esta tarea conlleva un conjunto de mecanismos políticos y jurídicos que deben responder al necesario equilibrio entre los valores de la paz y de la justicia en un marco de Estado Social de Derecho. La justicia transicional implica: i) el derecho a un recurso justo y eficaz; ii) Medidas restrictivas justificadas por la lucha contra la impunidad.

La justicia transicional debe evitar favorecer una estrategia jurídica de evasión de la justicia retributiva, a través del uso de las categorías de la justicia restaurativa y, principalmente, de las nociones de reconciliación y perdón (UPRIMNY; SAFFON, 2008, p. 178). Por ello, sostenemos que todo esquema de justicia transicional:

ha de revisar minuciosamente la combinacio $\bigotimes$ n de medidas retributivas y restaurativas que requiera para hacer compatibles reconciliacio $\bigotimes_{n}$ y justicia. No hay pues fo囚rmulas definitivas

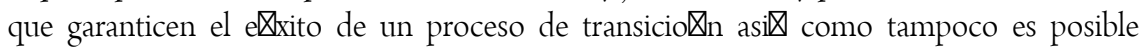

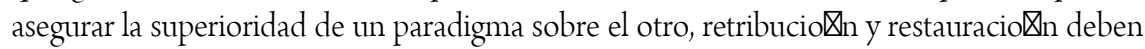
ser esquemas complementarios que garanticen los derechos de las vi囚ctimas, la construccio $\bigotimes$ n de la memoria comunitaria y el restablecimiento de la paz (RODRÍGUEZ MONTENEGRO, 2001, p. 57).

La justicia restaurativa, a diferencia de la retributiva, ofrece una gestión del conflicto que no es estrictamente la de la punición establecida en la legalidad sino que, a partir del acuerdo entre victimario y víctima, se acuerda una reparación ${ }^{11}$. Son numerosas las voces que se han alzado advirtiendo que el Derecho no está cumpliendo con uno de sus presupuestos básicos, como es el de castigar y punir cuando se ha vulnerado. La 
reparación simbólica pretende obtener un perdón de la víctima, un olvidar lo que ha sucedido, contraviniendo los propios fines del Derecho. Sin embargo, la construcción de la paz tampoco puede convertirse solamente en jurisprudencia (summum ius, summa iniuria). Sandrine Lefranc sostiene que:

renunciar a la facultad de castigar es simplemente otra manera de administrar justicia en cuanto que el fundamento político de la amnistía es idéntico al fundamento del ejercicio del poder punitivo: la intención subyacente a esos dos elementos, la amnistía y la autoridad punitiva es en última instancia, alcanzar la paz y la tranquilidad de todos los miembros de la comunidad (LEFRANC, 2005, pp. 163-186).

Los genocidios de Ruanda fueron escandalosos, ante la pasividad de la comunidad internacional. Sin embargo, el proceso de reconciliación que se ha llevado a cabo para reconstruir la comunidad ha sido ejemplar. Una justicia transicional a cualquier precio, eliminando a quienes aparecen como traidores, puede desembocar en unas consecuencias dañosas, engendrando de nuevo al monstruo al que se pretendía eliminar. La memoria vengativa dificulta el tránsito a la democracia. El componente de transformación de la memoria, para que se abra a la reconciliación y al olvido es, probablemente, la tarea más dificultosa.

Los expertos de la política saben bien que explotar las rabias, los rencores y los deseos de venganza de los electores es "una economía política" de jugosos réditos electorales (NARVÁEZ, 2013). Es la "economía del odio" a la que Savater denomina "Los recuerdos envenenados", y a la que David Rieff cuestiona en su libro "Contra la Memoria", y Svetlan Teodorov llama "Los abusos de la memoria" (Teodorov, 2000). Los tres autores afirman la importancia y urgencia de hacer re-composición de la memoria" (NARVÁEZ, 2013).

Somos críticos con respecto al uso de la justicia restaurativa como paradigma dominante de la justicia transicional en general (UPRIMNY; SAFFON, 2008, p. 180). La justicia transicional no consiste en una justicia penal suave frente a leyes severas. Reconocemos la presencia de la justicia restaurativa en la justicia transicional pero sin dejar de lado el componente de justicia retributiva. Los mínimos estándares jurídicos sobre derechos de las víctimas, imponiendo ciertas restricciones, deben acompañar la justicia transicional para que no se convierta en un mero juego de principios y valores, de tensiones que se mueven al compás de la doctrina principiológica. Entre el maximalismo jurídico (perdón y olvido) y el minimalismo (primacía de los derechos de las víctimas, sin importar las negociaciones de paz), la justicia transicional debe encontrar el justo equilibrio (un grado mínimo de justicia punitiva, acompañado de una satisfacción plena de la verdad y de la reparación) (UPRIMNY; SAFFON, $2008)^{12}$.

Por regla general, se suele sostener que el Estado debe investigar y satisfacer a las víctimas en su derecho a saber y a la verdad. Pero muy pocos teóricos defienden que el Estado debería centrar también sus esfuerzos en compensar a las víctimas (restitución). Por ello, Radzik (2015, p.304) defiende que el mal exige una respuesta

\footnotetext{
${ }^{11}$ En estos procesos, las técnicas de argumentación y negociación, sobre las que no podemos extendernos ahora, juegan un papel estratégico en orden a una adecuada gestión del proceso. Cf. Páramo Argüelles (2013, pp. 3-25).

${ }^{12}$ Uprimny, $R$; Saffon, Ma.P (2008). "Usos y abusos de la justicia transicional en Colombia”, cit, p.22. Cf, también Uprimny; Safon vol.10, no. 01, Rio de Janeiro, 2017.pp.333-364 
mucho más completa: exige la reconciliación moral, junto con las metas secundarias de la mejora moral, la comunicación respetuosa y la reparación.

En los procesos de paz suele ser habitual recurrir a sistemas alternativos de enjuiciamiento, como tribunales especiales negociados y acordados políticamente- o incluso sistemas de reconocimiento de culpa con solicitud de perdón que conlleva la amnistía: "La amnistía no puede ser acordada a los autores de violaciones en tanto las víctimas no hayan obtenido justicia por la vía de un recurso eficaz". Las fórmulas de prescripción también son comunes: "La prescripción no puede ser aplicada a los crímenes graves que según el derecho internacional sean considerados crímenes contra la humanidad." En cualquier caso, la justicia exige la reparación a la víctima, para lo que se deberán de adoptar "la creación de instrumentos y formulas encaminados a evitar la impunidad, la indulgencia o excesiva generosidad en la aplicación de las penas y consiguientemente el desconocimiento y menosprecio por las víctimas a los derechos humanos o al derecho internacional humanitario" (ARDILA).

La tendencia actual del Derecho Internacional de los derechos humanos es la de la exigencia del cumplimiento de esos requisitos en las formas, el sentido y el alcance de las investigaciones en el ámbito nacional sobre violaciones graves a los derechos en el marco de los sistemas de justicia transicional. De lo contrario, constituye un argumento para la revisión en tribunales internacionales de los procesos en contra los supuestos victimarios, más allá del principio de cosa juzgada. En esta línea ya se manifestó en su momento el Tribunal Militar Internacional de Nüremberg cuando afirmó que "los individuos tienen obligaciones internacionales que trascienden las obligaciones nacionales de obediencia impuestas por el Estado de que se trate" (BOTERO, 2000, p.8).

\section{El derecho a la memoria histórica y a la verdad}

El derecho a la memoria y a la historia constituye el primer eje vertebrador de la justicia transicional. Las verdades de la historia se sostienen sobre la referencialidad a los documentos y monumentos que nos llegan del pasado, pero también sobre las teorías, los métodos y las técnicas que permiten describir y explicar los acontecimientos que resultan de interés en cada presente. Por eso los productos de la historia son construcciones que tienen fecha de caducidad: porque los problemas del pasado que requieren explicación cambian en cada presente, porque las teorías, los métodos y las técnicas cambian, porque los restos del pasado cambian de significación en relación con lo que sucede en el futuro de esos acontecimientos, un futuro que ahora está ya en nuestro pasado o es nuestro presente. Por eso, cada generación tiene que rehacer la historia toda ${ }^{13}$. La historia es recuerdo y olvido, pero, además, es mucho más. 
Torralba (2015) diferencia entre historia y memoria. "La historia es una práctica epistémica disciplinada que genera una forma de conocimiento con pretensiones de verdad, la cual se basa en una racionalidad construida y convencionalizada entre quienes dominan esa forma de arte" (PITTAVINO et al, 2008, p. 3). La memoria, por el contrario, es una facultad individual. Dicho de otra manera, es una entidad supuesta (ficticia), responsable de los recuerdos y de los olvidos, y capaz, por tanto, de poder imaginar lo ya desaparecido, o de renunciar a hacerlo (Ibíd.). "Estrictamente lo u囚nico que existe es el recuerdo, mientras que el olvido es la ausencia de recuerdo, sea porque en el pasado algunos acontecimientos no llegaron a codificarse (...) o porque fueron activamente inhibidas, o porque no cuadran con los propo®sitos o el argumento desde los cuales se enuncian los recuerdos que ahora se evocan" (CARRETERO, ROSA et al., citados en PITTAVINO et al., p. 3).

"Mi identidad personal es, al mismo tiempo, identidad social, y ambas se basan en el recuerdo, pero también en el olvido. Hay partes de mi pasado que atesoro, pero también hay otras que repudio, que ignoro, que me gustaría que no hubieran existido" (ROSA, 2013, p. 44). Hay partes de mi pasado que no me son útiles para argumentar la idea que yo tengo de mi futuro y que, por tanto, descarto de mi argumento (Ibíd). Pero, además, los actos del recuerdo, cuando se comunican, son también actos del habla. Algo que nos lleva a una reflexión sobre la relación entre memoria y verdad.

La memoria es una facultad individual, pero los colectivos también recuerdan. La memoria colectiva es, pues, todo lo que acabamos de mencionar, pero también los mitos, el arte, los relatos compartidos, todo un imaginario que hace resonar en cada uno los mismos significados, las mismas sensaciones, lo que nos permite vivir en el nosotros, distinguiéndonos de los otros. Cuando una comunidad lleva tiempo viviendo junta, ha desarrollado ya sus formas de simbolización, de emoción, de recuerdo compartido, de celebración de la identidad $\operatorname{propia}^{14}$.

El vínculo de la memoria con la teoría de la justicia es evidente. Y aunque la memoria nos remonte al pasado, resulta indudable su proyección en el futuro. Saravia Méndez ha subrayado que "el carácter multiforme de la memoria como fenómeno humano permite que en su seno se den cita una variedad amplia de dimensiones epistemológicas" (SARAVIA MÉNDEZ, 2014, p. 1). Efectivamente, el sujeto de la memoria puede ser tanto la primera persona del singular como un colectivo de sujetos unidos por lazos familiares, la proximidad, la

\footnotetext{
${ }^{14}$ Carreras y Forcadell (2003) nos ofrece un conjunto de magníficos estudios sobre los usos públicos de la historia. Este trabajo nos recuerda cómo los historiadores derivan de los cronistas reales, o cómo la Real Academia de la Historia (de España) se funda en el siglo XVIII, recibiendo entre sus encargos "ajustar la historia a los intereses políticos de la nación y derechos de la Corona, sosteniéndolos contra los de las naciones rivales, o de las provincias conquistadas" (p.13). Para los historiadores, "si bien la historia es una ciencia, el patriotismo era una virtud a cuyo servicio debía ponerse esta forma de conocimiento” (ibídem). De esta manera, la historia se pone al servicio de la política, inaugurándose una lucha discursiva (y con demasiada frecuencia no sólo simbólica) sobre cuál es la correcta interpretación del pasado, sobre quienes la poseen, sobre quién dispone de las claves para interpretar el nosotros, sobre quiénes son los que están de acuerdo con el sentido y con el destino de la colectividad. En definitiva, sobre quiénes son los leales a la esencia de la patria, o los traidores a ella. La batalla del discurso histórico se convierte en la batalla por la identidad, se funde con la batalla por la definición de qué comunidad política, de qué cives, de qué ciudadanía.
} 
nacionalidad u otras formaciones sociales. En cuanto a las funciones que la memoria cumple, para unos se trata de un deber moral, el único antídoto eficaz contra la barbarie. La fórmula que sintetiza a esta postura sería: conocer la historia para evitar que se repita. Para otros, por el contrario, el olvido es un mal necesario si lo que se pretende es garantizar la viabilidad de una vida social y política relativa mente estable. El lema sería, en este caso, no remover el pasado porque entraña el peligro de reabrir viejas heridas (SARAVIA MÉNDEZ, 2014).

El derecho a la verdad completa el derecho a la historia y a la memoria en la justicia transicional. Las víctimas de graves violaciones de los derechos humanos y del derecho internacional humanitario, así como sus familiares, tienen el derecho a un recurso efectivo. Esto implica el derecho a saber la verdad acerca del abuso que han sufrido, incluyendo la posibilidad de identificar a los perpetradores, las causas que originaron tales violaciones y, de ser el caso, la suerte final o el paradero de las personas desaparecidas de manera forzada. Este derecho ha sido reconocido en decisiones legales tomadas por las cortes en varios países, así como por instituciones judiciales internacionales.

El derecho a la verdad no puede limitarse a un mero slogan. Debe vincularse al derecho a un recurso efectivo e incluir el derecho a una investigación efectiva y a la verificación de los hechos y la presentación pública de la verdad, así como el derecho a la reparación. Además de las víctimas individuales y sus familiares, las comunidades y la sociedad entera también tienen el derecho de saber la verdad acerca de las violaciones de los derechos humanos Algunos sistemas legales consideran que el derecho a la verdad hace parte integral de la libertad de información y la libertad de expresión (GONZÁLEZ; HOWARD, 2013,p. 7).

El derecho a la verdad debe buscarse tanto a través de procedimientos judiciales como no judiciales. El Estado debe intentar establecer la verdad acerca de los abusos y violaciones independientemente de los juicios penales que puedan corresponder. Es decir, las medidas no judiciales también pueden ser necesarias para satisfacer el derecho a la verdad. Entre estas medidas cabe destacar establecer comisiones de la verdad y otras comisiones no judiciales de investigación, reforzar las leyes que protegen la libertad de información y de expresión y desarrollar expresiones de recuerdo y conmemoración como, por ejemplo, monumentos y museos. (GONZÁLEZ; HOWARD, 2013, p. 8).

El esclarecimiento de la verdad puede iniciar el proceso de reconciliación en tanto que la negación y el silencio pueden incrementar la desconfianza y la polarización. El conocimiento de la verdad, de lo que realmente sucedió, es imprescindible para acabar o, al menos, aminorar sospechas, y construir una sociedad con perspectivas de futuro. Un orden político basado en la transparencia y la rendición de cuentas tiene más posibilidades de disfrutar de la seguridad y confianza de sus ciudadanos que un sistema en el que se ocultan o se intentan tapar hechos históricos.

El derecho a la verdad no ha sido objeto de ninguna Convención internacional específica. El debate legal en torno al derecho a la verdad discute si este se deriva de varios derechos bien establecidos en el Derecho vol.10, nº. 01, Rio de Janeiro, 2017.pp. 333-364 
internacional, como por ejemplo el derecho a la reparación, el derecho a recibir e impartir información y el derecho al debido proceso; o si es más bien un derecho autónomo independiente o adicional a estos otros derechos. No obstante, los elementos principales de este derecho están bien aceptados. Así, La Comisión y la Corte del Sistema Interamericano de Derechos Humanos han confirmado que el derecho a la verdad se halla establecido en la Convención Americana sobre Derechos Humanos conforme a las disposiciones que amparan el derecho a un juicio justo, libertad de pensamiento y expresión y el derecho a la protección judicial (GONZÁLEZ; HOWARD, 2013, p. 9).

El derecho a la verdad, en el ámbito de la memoria histórica ${ }^{15}$, tropieza con un conflicto entre derechos. Por una parte, quienes reivindican el deber de memoria y, por otra, quienes sostienen unas razones para el olvido. Estas dos posiciones extremas, derivan, como sostiene Narváez, de dos lógicas enfrentadas como son, por una parte, la lógica del maximalismo moral que reclama la aplicación de la justicia en todo su rigor sin importarle que se prolonguen períodos de justicia sin democracia; y, por otra parte, la lógica del minimalismo pragmático que reclama la consolidación de la democracia sin justicia. Estos dos extremos pueden superarse con la aplicación de la cultura política del perdón y de la conciliación como expresión de una "tercera vía moral". Todo ello tiene un sentido teleológico, como es el de desembocar en la reconciliación. Es decir, la reconciliación provee cuatro componentes que hoy día se consideran fundamentales para transiciones pacíficas a la democracia: verdad, justicia, reparación y garantías de no repetición (NARVÁEZ, 2013) ${ }^{16}$.

El derecho a la verdad también tropieza con otros obstáculos que pueden acabar distorsionándola, como es la memoria petrificada y vengativa (hipermnesia) por parte de los ciudadanos de países que han vivido períodos de violencia interna. Esta situación conlleva una limitación del ejercicio de la democracia al desconocer la interpretación histórica del sentido de las causas de las violaciones masivas de Derechos Humanos, generando procesos sociales de exclusión y nuevas violencias. (Narváez, 2013).

Tras la Segunda Guerra Mundial asistimos a una especie de "nueva conciencia humanitaria" que coloca el acento político y cultural en un "retorno político y judicial al trauma histórico" y a una especie de "primado" ético de la memoria sobre el olvido y de la justicia sobre la impunidad (JARAMILLO; DELGADO, 2011) ${ }^{17}$. Algunos autores, como Benjamín, sostienen que la historia estaría del lado del vencedor y "de los herederos de todos aquellos que vencieron alguna vez".

\footnotetext{
${ }^{15}$ Cf. Benjamin (2005).

${ }^{16}$ Narváez (2013): “Memoria y democracia”. Disponible en: http://revista.drclas.harvard.edu/book/memoria-y-democracia (consultado por última vez el 1.11.2015).

${ }^{17}$ La justicia transicional en Colombia ha sido objeto de numerosos estudios, entre los que cabe destacar: Uprimny, $R$. y Saffon, Ma.P (2008). Usos y abusos de la justicia transicional en Colombia, pp.1-31. [Disponible en <www.anuariocdh.uchile.cl>]. 
Desde los años ochenta se ha hecho habitual afirmar que hay que hablar del pasado para permitir superar los traumas, para administrar el dolor y para alzar la vista hacia perdones y reconciliaciones. Desde los juicios de Nüremberg hasta el Tribunal Penal Internacional, la reconstrucción del pasado se ha hecho no en clave de perdón y reconciliación sino como instrumento de justicia, aplicando el principio clásico de "el que la hace la paga". La constitución de estos tribunales pretendía saldar deudas históricas con las víctimas de los conflictos. La recuperación de la memoria histórica, revivir dolorosos recuerdos para cerrar heridas y construir un presente que mire al futuro. Sin embargo, tampoco han faltado las críticas a este proceso acusándolo de "instrumentalización del pasado", "bulimia conmemorativa", "hiperculto del testimonio", "hipertrofia de la historia" e "ideologización memorial" (Ibíd.).

La metodología que se aplique para llegar al conocimiento de la historia y de la verdad, cobra especial protagonismo. Nos adherimos a la opinión de Lessa cuando apunta que "las decisiones de justicia transicional nunca son permanentes, sino que se desarrollan continuamente y soportan escrutinio a lo largo del tiempo" ${ }^{18}$. Por lo tanto, el análisis de la justicia transicional es un proceso a largo plazo cuya trayectoria está moldeada por una multitud de actores y factores, por lo que sus diseñadores nunca controlan totalmente el proceso que ponen en marcha (LESSA, 2013, p.217)

El derecho a la verdad y, con él, la memoria histórica, han hecho uso de diversos mecanismos para conocer la verdad y para representar el dolor sufrido. Desde tribunales internacionales hasta comisiones históricas y cortes de justicia locales. Desde programas de asistencia legal hasta mecanismos de reparacioØn material y

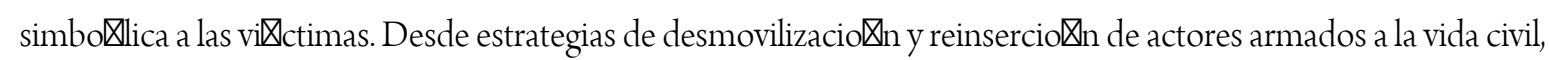
hasta el disen o y ejecucio囚n de "lugares de memoria" y construccio $\bigotimes_{n}$ de escenarios de convivencia (REYES MATE, 2008). Todos ellos con el aparente objetivo de impartir justicia y buscar caminos de reconciliacio囚n (JARAMILLO; DELGADO, 2011, p.134).

Como principales elementos para configurar una política de justicia transicional cabe destacar, en palabras del Centro Internacional para la Justicia Transicional (ICTJ) ${ }^{19}$ :

\footnotetext{
${ }^{18}$ Lessa hace especial hincapié en el papel que han jugado los principales actores: el ejecutivo, la sociedad civil, los jueces y las fuerzas armadas. Sousa Santos también ha destacado el papel que desempeñan las narrativas del sufrimiento y la liberación: " [ ... ] contar historias genera un inmediato y concreto sentido de copresencia a través del cual se tornan más fácilmente accesibles e inteligibles las experiencias sociales que se producen en varios tiempos, espacios y culturas, un tipo de copresencia que no es posible conseguir a través del lenguaje conceptual (ya sea técnico, filosófico o científico)" (SOUSA SANTOS, 2014:101).

${ }^{19}$ En este ámbito, destacamos la labor del Centro Internacional para la Justicia Transicional (ICTJ), que es una organización internacional sin ánimo de lucro especializada en la justicia en periodos de transición. "El ICTJ tiene el objetivo de remediar y prevenir las graves violaciones de los derechos humanos, con el fin de enfrentarse al legado de los serios abusos cometidos durante los conflictos armados o regímenes autoritarios. Para cumplir esta misión, utiliza amplios conocimientos adquiridos en diversos países asesorando a comisiones de la verdad, programas de reparación y a otras entidades que promueven la justicia transicional. El ICTJ trabaja junto con los Gobiernos, la sociedad civil y otros organismos que velan por la defensa de los derechos de las víctimas así como por la búsqueda de soluciones integradas para promover la rendición de cuentas y crear sociedades más justas y pacíficas" (ICTJ, 2015). Al respecto puede consultarse la página web del ICTJ: <http://ictj.org/es/que-es-la-justicia-transicional> (consultado por última vez el 2.11.2015).
} 
1. Las acciones penales, principalmente contra los criminales considerados de mayor responsabilidad.

2. Las reparaciones que los Gobiernos utilizan para reconocer los daños sufridos y tomar medidas para abordarlos. Esas iniciativas suelen tener un componente material (como los pagos monetarios o los servicios sanitarios), así como aspectos simbólicos (como las disculpas públicas o los días del recuerdo).

3. La reforma de instituciones públicas implicadas en los abusos -como son las fuerzas armadas, la policía y los tribunales-, con el fin de desmantelar, con los procedimientos adecuados, la maquinaria estructural de los abusos y evitar tanto la repetición de violaciones de derechos humanos graves como la impunidad.

4. Las comisiones de la verdad u otras formas de investigación y análisis de pautas de abuso sistemáticas, que recomiendan cambios y ayudan a comprender las causas subyacentes de las violaciones de derechos humanos graves (ICTJ, 2015).

En esta fase transicional, desde los años ochenta son diversos los países que se han sumado a esta vía: Argentina, Chile, Uruguay, Sudáfrica, Guatemala, Salvador, Irlanda del Norte, Burundi, Sri Lanka, Ecuador, Colombia ${ }^{20}$, Brasil y, también España. Los instrumentos utilizados han sido variados: Discursos llenos de buenas intenciones, levantamiento de monolitos y monumentos recordatorios, Comisiones de Verdad, de Reconciliación o de Esclarecimiento Histórico, hasta políticas gubernamentales de reinserción. En unos casos, operaron con mandatos presidenciales o internacionales de corta duración para investigar los hechos de violencia y sus causas generadoras, durante un período determinado de tiempo. Otras muchas contaron con un relativo grado de legitimidad política y social en su proceder y generaron recomendaciones a los gobiernos de turno para llevar a cabo procesos de reconciliación futuros (JARAMILLO; DELGADO, 2011, p. 134).

En algunos países se "decretó por arriba" el cierre del pasado en busca de una transición democrática, como fueron los casos de España, Uruguay y Brasil. En otros casos, la "reconciliación nacional" pactada por ciertos grupos (los responsables de los nuevos gobiernos democráticos, los poderes de facto del antiguo régimen y algunas organizaciones de derechos humanos), llegó a traducirse en "reconciliación social”, en reconstrucción del tejido desde abajo (REYES MATE, 2008) (JARAMILLO; DELGADO, 2011, p. 135). Y también hubo otras sociedades en que, a pesar de que había cierto grado de esperanza, los acuerdos nacionales terminaron siendo "papel mojado", al no sustentarse sobre bases sociales amplias y cambios estructurales, como posiblemente sucedió en los casos del Salvador y Guatemala (Ibíd. $)^{21}$.

En el contexto latinoamericano, las frágiles democracias latinoamericanas cedieron el poder a cúpulas

\footnotetext{
${ }^{20}$ La Fundación para la Reconciliación en Colombia "ha propuesto la generación de una cultura política de perdón y reconciliación (Escuelas de Perdón y Reconciliación -ESPERE-). Proceso pedagógico en el que los participantes reunidos en pequeños grupos, después de garantizar ambientes seguros de total confidencialidad, cuentan a otros la historia de sus traumas para generar empatíaatención-cuidado que permite revivir la herida de manera diferente en el giro narrativo que transforma la memoria”. Al respecto puede consultarse la página web de la Fundación: <www.fundacionparalareconciliacion.org> (consultado por última vez el 2.11.2015).

${ }^{21}$ Cf. Rincón (2010); Reyes Mate (2008).
} 
militares y el fantasma de la dictadura militar se instaló con mucha facilidad reemplazando a los débiles gobiernos constitucionales. Una vez reconducidas esas situaciones, y con la vuelta de los civiles a dirigir el Estado, surge el inevitable dilema de qué hacer con los responsables de las violaciones a los derechos humanos. “¿Cómo reconstruir las sociedades maltratadas, cómo restablecer la paz, cómo buscar la reconciliación nacional, sin hacer justicia?" (CUYA Y MENSCHENRECHTSZENTRUM, 1996).

Casi de forma generalizada, los propios regímenes militares, antes de dejar el poder, trataron de cerrar la etapa de la historia que ilegítimamente habían capitaneado y procuraron neutralizar cualquier posibilidad de enjuiciamiento posterior de sus actos de gobierno y de sus violaciones a los derechos humanos. Con el propósito de borrar el horror de sus acciones, y de conseguir el olvido y la impunidad, estos regímenes dictatoriales, al final de su mandato o los gobiernos que les sucedieron, dictaron leyes de "Obediencia debida", "Caducidad" "Punto Final", "Amnistía", u otras fórmulas. Sin embargo, a raíz del clamor de justicia de los familiares de las víctimas, así como a la lucha de algunos abogados, periodistas, religiosos, magistrados, políticos y activistas internacionales de solidaridad, se crearon las comisiones investigadoras de la verdad. En esta línea, desde instancias del poder oficial, se constituyó, en Argentina, la CONADEP, (Comisión Nacional sobre la Desaparición de Personas); en Chile, la "Comisión de Verdad y Reconciliación"; y en El Salvador, la "Comisión de la Verdad". En otros casos, como ocurrió en Brasil, Uruguay, Paraguay, Bolivia, las Comisiones de la Verdad, surgieron como una opción ética, un esfuerzo directo, a veces clandestino, de los activistas y organismos de derechos humanos, sin contar con el mandato gubernamental (CUYA Y MENSCHENRECHTSZENTRUM, 1996).

Los responsables de las violaciones a los derechos humanos, así como determinados sectores no golpeados por la violencia oficial, propusieron llegar pronto a la reconciliación de la sociedad con la excusa de que había que intentar reconstruir el país cuanto antes. No tenían ningún interés en conocer la verdad de los hechos y menos de que se hiciera justicia. Pero hay que recordar que la Comisión Interamericana de Derechos Humanos estableció que "Toda sociedad tiene el irrenunciable derecho de conocer la verdad de lo ocurrido, así como las razones y circunstancias en las que aberrantes delitos llegaron a cometerse, a fin de evitar que esos hechos vuelvan a ocurrir en el futuro" (CIDH, 1986). El derecho a la verdad constituye una parte de la reparación del daño ocasionado por los agentes del Estado. Y esa reparación debe incluir además medidas de carácter económico, social, médico, jurídico, para tratar de reivindicar la memoria de las victimas y aliviar en parte la tragedia ocasionada a los familiares afectados (CUYA Y MENSCHENRECHTSZENTRUM, 1996).

\section{El derecho a la reparación}

El derecho a la reparación de la víctima es el tercer principio en el que se sustenta la justicia transicional. Las medidas pueden ser variadas: 
1. Medidas de restitución, con la finalidad de que la víctima pueda volver a la situación anterior a la violación);

2. Medidas de indemnización, al efecto de paliar o compensar un perjuicio psíquico y moral, así como pérdida de una oportunidad, daños materiales, atentados a la reputación y gastos de asistencia jurídica); y

3. Medidas de readaptación, que incluyen la atención psicológica y psiquiátrica).

\section{¿Es imprescindible el perdón en la justicia transicional?}

El perdón desempeña un importante papel en la justicia transicional. Por una parte, los victimarios deben de pedir perdón. Por otro, se espera de las víctimas que acepten este perdón. Pero detrás del perdón hay un complejo entramado: venganza, impunidad, rencor, castigo, culpabilidad, reconciliación y tantos otros.

Valcárcel apunta que el origen de toda justicia es el talión ${ }^{22}$. Como sabemos, la violencia abre la puerta a una cadena interminable de venganzas. "Para romper esa cadena se ha inventado la ley, que cierra las venganzas porque, por así decirlo, se venga por el ofendido. Pero la ley se desentiende de la víctima, lo que le importa es el delito, y eso implica que hay algo que siempre va a quedar sin pagar" (VALCÁRCEL, 2011).

El perdón, a diferencia de la venganza y del rencor, implica una renuncia a castigar. El perdón, para Ricoeur (2004), está en un nivel supraético. Sostiene que el olvido tiene que ver con la memoria y la fidelidad al pasado; el perdón, en cambio, con la culpabilidad y la reconciliación con ese pasado. Llama al perdón el "apaciguamiento de la memoria" y le da al olvido el mismo rango de la memoria y de la historia (RICOEUR, 2004).

Para entender el perdón en sus debidos términos, hay que tomar en consideración la relación existente entre incondicionalidad y condicionalidad del perdón. Para Rodríguez Peña (2012), el único perdón que tiene sentido es aquel que perdona lo imperdonable. El perdón participa de una dialéctica que juega con valores morales: desde lo imposible-imperdonable (no existe posibilidad de hacer justicia sobre el crimen y, a la vez, la víctima no perdona) pasando por lo posible-perdonable (se hace justicia, y la víctima perdona) y terminando en lo posible-imperdonable (se hace justicia pero la víctima decide no perdonar al victimario) (RODRÍGUEZ MONTENEGRO, 2012) 23 .

El perdón ha sido objeto de análisis desde perspectivas muy diversas como la religión, la política, el derecho, las ciencias sociales, la psicología y la filosofía, iniciando su andadura desde un ámbito espiritual, siguiendo por un ámbito teórico y terminando en una diversidad de maneras de llevarlo a la práctica. Ello permite

\footnotetext{
${ }^{22}$ Vid. Valcárcel (2011), quien subraya que "el cristianismo triunfa porque es la gran religión del perdón, es la respuesta a un mundo que quiere un cierto tipo de unidad que la filosofía no ha sido capaz de darle porque la filosofía es para élites. Perdonar es la instrucción más constante, que está en la oración fundacional, el «Padre Nuestro», que nos dice que todos los días hay que comer y perdonar". Es el perdón como "una soberbia innovación moral".
} 
distinguir, siguiendo a Rodríguez Peña (2012), entre un perdón redentor, un perdón incondicional y un perdón condicionado.

En el ámbito político, el poder condicionado deriva de un discurso retórico donde el Estado juega un doble papel, pide perdón "en nombre" de las victimarios y lo concede "en nombre" de las víctimas (RODRÍGUEZ PEÑA, 2012, p. 12). A su vez, este poder condicionado, puede dividirse, en primer lugar, en un perdón de carácter retributivo, que hace que el castigo se convierta en una condición de este, es decir, que para otorgar el perdón se debe imponer un castigo al victimario (RODRÍGUEZ PEÑA, 2012, p. 13). En segundo lugar, el carácter restaurativo del perdón exige que para que la víctima perdone, debe ser empoderada (Ibíd.). En tercer lugar, el perdón reconciliador, que deriva de la necesidad de confianza que debe de existir entre los individuos que integran las comunidades políticas. Los actos violentos hacen que las personas pierdan su confianza (Ibíd.). El perdón surge como elemento restaurador de esos lazos de confianza pero necesita que la víctima perdone, que el victimario reconozca su crimen y pida perdón y que la comunidad política reconozca a la víctima (Ibíd.). Por último, el perdón finalizado, donde la amnistía y el indulto son los protagonistas, es el que ejerce el Estado sin tener en cuenta a la víctima, ya que la intención de este perdón es restaurar el orden y la armonía social, sin tomar en consideración el sentir de las "víctimas" (Ibíd.).

Rodríguez Montenegro, adoptando una perspectiva más jurídica que filosófica, diferencia tres modelos de perdón. El primer modelo es el de los perdones amnésicos tales como amnistías generales sin estrategias de verdad o reparación. Las experiencias de España y de Portugal de la década del 70 y las amnistías colombianas de los 80 se inscriben en esta categoría. "Se trata de procesos transicionales en los que se busca facilitar la negociación entre los actores y la reconciliación ulterior a través del olvido" (RODRÍGUEZ MONTENEGRO, 2010, p. 6). Este tipo de perdón tiene unos inconvenientes. Además de que éticamente no son deseables, en la medida en que ocultan la verdad sobre los responsables de los crímenes en detrimento de los derechos de las víctimas, dificultan la consecución de una paz sostenible a largo plazo (Ibíd.). Actualmente, el Derecho Internacional impide de entrada las amnistías generales de criðmenes de lesa humanidad y criðmenes de guerra, lo que único a la presio $\bigotimes_{n}$ de los movimientos de vi邓ctimas y de la comunidad internacional, "hace que el perdo $\llbracket n$ amne区sico sea una salida poco viable”. (RODRÍGUEZ MONTENEGRO, 2010, p. 6).

El segundo modelo es el de los perdones compensadores, "los cuales buscan un equilibrio entre los derechos de las víctimas y los requerimientos para la negociación con miras a la paz. Recubren la forma de amnistías generales con comisiones de la verdad y algunas medidas de reparación para los afectados" (Ibíd.), tales como las que se aplicaron en Chile y en El Salvador. Este modelo ha sido objeto de críticas en la medida en que parece partir de una supuesta intercambiabilidad entre los derechos de las víctimas y las penas imputables a 
quienes las han llevado a cabo, de manera que si un Estado garantiza el esclarecimiento de la verdad y una reparación mínima a las víctimas puede eximirse de castigar a los responsables de los crímenes (Ibíd.). El modelo de perdones compensadores no toma en consideración la función que el castigo desempeña "en cualquier proceso de transición y refundación del orden social. No se puede sentar las bases de un régimen sin impunidad que condena ética y políticamente los actos de violencia y reconoce suficientemente los derechos de las víctimas" (Ibíd.).

El tercer modelo es el de perdones responsabilizantes, propia de negociaciones de paz que buscan garantizar los derechos de las víctimas y los deberes del Estado en relación al esclarecimiento de la verdad (Ibíd.), "el castigo de los victimarios y la reparación de los afectados. La concesión de perdones es excepcional e individualizada y se rige por el principio de proporcionalidad" (RODRÍGUEZ MONTENEGRO, 2011, p. 55) según el cual, "el perdón de los victimarios sólo es justificable cuando es la única medida que puede hacer posible el logro de la paz y la reconciliación nacional". Para ello se exige que "se corresponda con la gravedad de los actos cometidos por el inculpado, su grado en la jerarquía de mando y las contribuciones que haga a la justicia" (UPRIMNY; LASSO, 2004, p. 92). Aquí entra en juego el principio de proporcionalidad que, según Rodríguez Montenegro (2010), estaría delineado por tres máximas que son: 1) A mayor gravedad del crimen, menor posibilidad de perdón.; 2). A mayor responsabilidad militar (nivel de mando) o social del victimario, menor posibilidad de perdón; 3) A mayor contribución a la paz, a la verdad y a la reparación, mayores posibilidades de perdón (RODRÍGUEZ MONTENEGRO, 2010,p.7).

En cuarto y último lugar se encuentran "las transiciones punitivas, caracterizadas por el establecimiento de tribunales para castigar a los responsables de crímenes de guerra y lesa humanidad” (Ibíd.). Los instalados en Nüremberg, Rwanda y Yugoslavia constituyen una muestra. La base de esta "modalidad es que sólo el castigo de los responsables permite la fundación de un nuevo orden democrático basado en los derechos humanos, por lo que los indultos, amnistías y políticas de perdón" (Ibíd.) no deberían de aceptarse (Ibíd,).

En definitiva,

de los cuatro modelos de justicia transicional dos son radicales (I y IV) y dos son intermedios (II y III) en lo que respecta al contenido de sus fo囚rmulas. Para Uprimny y Lasso (2004), los modelos radicales basados en perdones amne囚sicos (I) y en transiciones punitivas (IV) no son, en realidad, verdaderos tipos de justicia transicional, en la medida que no se encuentran atravesados por el dilema de esta u囚ltima, pues aunque ambos describen la transicio $\rrbracket \mathrm{n}$ de un estado de guerra a uno de paz o de una dictadura a una democracia, dicho cambio no resuelve la tensio $\ \mathrm{n}$ entre justicia y paz a trave $\bigotimes_{\mathrm{s}}$ de la consecucio $\bigotimes \mathrm{n}$ de un equilibrio entre las dos exigencias, sino que escoge una sola de ellas (RODRíGUEZ MONTENEGRO, 2011, p. 55$)^{24}$.

\footnotetext{
${ }^{24}$ Cf. Cortés (2009, pp.85-112).
} 


\section{JUSTICIA TRANSICIONAL EN LOS PROCESOS DE PAZ: ESPECIAL REFERENCIA A BRASIL Y A COLOMBIA}

Son muchos los países que han experimentado un proceso de justicia transicional, como venimos explicando, tanto en el cono sur latinoamericano, como en Centroamérica, en Europa, repartidos por toda la geografía. Vamos a destacar, de forma muy sumaria, algunos de los aspectos más significativos de estos procesos de paz en Brasil y en Colombia. 25

En Brasil, la investigación comenzó en agosto de 1979 y concluyó en marzo de 1985. En ese período se logró sistematizar informaciones contenidas en 707 expedientes de procesos llevados ante el Tribunal Militar Supremo. Por esto, una característica del Informe es que se basa, fundamentalmente, en documentos oficiales de los procesos judiciales llevados a cabo por los Tribunales militares contra activistas y opositores políticos.

El resultado del trabajo se difundió en volúmenes de más de 5000 páginas (Proyecto A) con el título Brasil Nunca Mais ${ }^{26}$. En 1995, el gobierno brasileño aprobó el DL 869/95 con el propósito de otorgar una reparación económica a los familiares de 136 personas desaparecidas durante las dictaduras militares. La Ley encarga otorgar una reparación económica de hasta US\$150,000 a cada familia de las personas asesinadas o

\footnotetext{
${ }^{25}$ En el contexto español también se ha experimentado un proceso de justicia transicional. España promulgó la Ley 52/2007, de 26 de diciembre, por la que se reconocen y amplían derechos y se establecen medidas en favor de quienes padecieron persecución o violencia durante la guerra civil y la dictadura, más conocida como Ley de Memoria Histórica (JULIÁ, 2006, pp.15-26). Incluye el reconocimiento de todas las víctimas de la Guerra civil (1936-1939) y de la posterior dictadura del General Franco (1939-1975). No se contemplaba la apertura de las fosas comunes en las que aún yacen los restos de represariados por los sublevados o bando nacional en la contienda por lo que se han ido realizando desde entidades privadas - tales como la Asociación para la Recuperación de la Memoria Histórica (ARMH) y el Foro por la Memoria- o entidades públicas como las Comunidades Autónomas. Bajo el gobierno presidido por Mariano Rajoy, la Ley de Memoria Histórica ha quedado derogada de facto, ya que en los Presupuestos Generales del Estado desde 2013 ha quedado sin dotación presupuestaria para su aplicación. Las opiniones sobre el derecho a la memoria histórica fueron muy controvertidas en relación a la tramitación de la ley española. Algunos sostuvieron que "ese pretendido nuevo derecho fundamental denominado derecho a la memoria personal y familiar" no era más que un derecho ficticio, sin contenido alguno, derecho inédito y no reconocido en ninguno de los pactos internacionales de derechos humanos. (ORTEGA y DÍAZ-AMBRONA, 2006). Otros añadieron que, en el caso de que se aceptara como tal derecho no sería más que un nuevo derecho moral porque es difícil que conllevara una reparación de carácter económico. Otros se lamentan de querer remover la historia y la memoria de un tema que ya ha sido superado, buscando nuevo enfrentamientos. Lo cierto es que esta ley sigue dando lugar a polémica, entre quienes sostienen que debería derogarse y aquellos otros que reclaman dotación y su efectivo cumplimiento.

${ }^{26}$ Actualmente se está trabajando en el proyecto Brasil Nunca Mais digital: "O Projeto Brasil Nunca Mais visava obter, através de processos envolvendo presos políticos, retirados do Superior Tribunal Militar e microfilmados, informações e evidências de violaçōes aos direitos humanos praticadas pelo aparato repressivo do Estado durante a ditadura militar. Essas informaçōes foram compiladas e analisadas em um documento-mãe, denominado "Projeto A", com 12 volumes. Considerando a dificuldade de leitura e até de manuseio desse trabalho, foi idealizado por Dom Paulo o "Projeto B", um livro que resumisse o "Projeto A", publicado pela Editora Vozes com o título de "Brasil: Nunca Mais". Tanto o "Projeto A", quanto as cópias integrais dos 707 processos foram transferidos, posteriormente, ao "Arquivo Edgard Leuenroth" da UNICAMP; os 543 rolos originais de microfilmes dos processos foram enviados ao "Latin American Microform Project" - "LAMP", mantido no "Center for Research Libraries - CRL", sediado nos Estados Unidos" < http://www.pucsp.br/cedic/projetos.html> (Acceso el 20/09/2014).
} 
desaparecidas que reconoce el gobierno. Pero los familiares de los desaparecidos, y de las otras víctimas siguen demandando el esclarecimiento de la verdad de lo que pasó con sus seres queridos y el castigo a los responsables.

En estos procesos de justicia transicional conviene prestar atención a cómo se ha gestado y aprobado la Ley de Amnistía, propia de estos procesos. Si se ha tratado de una Ley de Amnistía redactada por el estricto grupo de políticos en el poder, interesado en eliminar cualquier posibilidad de futura de responsabilidad futura por las acciones cometidas, entonces cabría calificarlo de auto-amnistía, porque es el propio grupo de individuos que ha cometido las actuaciones sospechosas el que se encarga de darse una legislación que les ponga a salvo de una punición futura. Este sería por ejemplo, el caso de Brasil y la Ley no 6.638 de 1979, denominada Ley de Amnistía, a la que podríamos clasificar como una de las Leyes "dictadas desde arriba". Ello ha derivado en que instancias supranacionales, años más tarde, dicten sentencias que acaban deslegitimando las Leyes de Amnistía que, en uso de su soberanía nacional, los diversos países han ido aprobando y que, sin embargo, desde el ámbito internacional, se cuestionan.

La Comisión Interamericana de Derechos Humanos denunció al Estado Brasileño por la detención arbitraria, tortura y desaparición forzada de 70 personas realizada por el Ejército Brasileño en las acciones de represión producidas entre 1972 y 1975. La Corte Interamericana de San José de Costa Rica, en su sentencia de 1 de noviembre de $2010^{27}$, concluyó que Brasil es responsable de la desaparición forzosa de 62 personas, producida entre los años de 1972 y 1974, en la región conocida como Aragüaia. En el citado caso se analizó, entre otras cuestiones, la compatibilidad de la Ley de Amnistía No. 6.683/79 con las obligaciones internacionales asumidas por Brasil a la luz de la Convención Americana sobre Derechos Humanos. Declaró expresamente que: "Las disposiciones de la Ley de Amnistía brasileña que impidan la investigación y sanción de graves violaciones de derechos humanos son incompatibles con la Convención Americana y carecen de efectos jurídicos, razón por la cual no pueden seguir representando un obstáculo para la investigación de los hechos del presente caso, ni para la identificación y sanción de los responsables".

El 14 de diciembre de 2011 Brasil remitió a la Corte el Informe sobre el cumplimiento de la sentencia ${ }^{28}$, indicando que había cumplido íntegramente lo estipulado (entre otras estipulaciones de la sentencia, destacamos: llevar a la jurisdicción penal ordinaria la investigación de los hechos para esclarecerlos y dictar las sanciones

\footnotetext{
${ }^{27}$ CIDH_CP-19/10 - Sentença do caso Gomes Lund e outros ("Guerrilha do Araguaia")

Vs. Brasil- (sentencia de 24 de noviembre de 2010). La Sentencia puede consultarse en: <http://www.corteidh.or.cr/docs/casos/articulos/seriec_219_por.pdf.> (Acceso el 12-12- 2014). Citado por GORCZEVSKI, C; COSTODIO LIMA, W. "Análisis das Políticas Públicas decorrentes da condenação do Brasil na Corte Interamericana nos casos Ximenes Lopes e. Garibaldi” en XI Seminario Nacional Demadas Sociais e Políticas Públicas na Sociedade Contemporánea, UNISC. Disponible en. https://online.unisc.br/acadnet/anais/index.php/snpp/.../2763.

en "As decisões da Corte Interamericana de Direitos Humanos e as políticas publicas brasileiras decorrentes" (En prensa).

${ }^{28}$ El Informe puede consultarse en T. LEME FRANCO, Efetividade das decisóes proferidas pela Corte interamericana de Direitos Humanos: identificação dos marcos teóricos e análise da conduta do Estado brasileiro:<http://2ccr.pgr.mpf.mp.br/coordenacao/grupos-de-trabalho/justica-de-transicao/relatorios-
} 
correspondientes, realizar los esfuerzos necesarios para establecer el paradero de las víctimas y desaparecidos y, si fuera el caso, identificar los retos y entregarlos a sus familiares; ofrecer tratamiento médico o psicológico a las víctimas que lo requieran; publicar en Boletín Oficial la sentencia y reconocer internacionalmente la responsabilidad del Estado, implementar un curso obligatorio de formación en derechos humanos para todos los niveles jerárquicos de las Fuerzas Armadas, tipificar el delito de desaparición forzada de las personas en consonancia con los parámetros interamericanos). Sin embargo, en abril de 2012, los representantes de las víctimas, a través de una manifestación, intentaban denunciar que el Estado Brasileño no había cumplido íntegramente las obligaciones establecidas en la sentencia ${ }^{29}$ ya que aún no había ofrecido tratamiento médico, psicológico y psiquiátrico a las víctimas que lo habían solicitado (las publicaciones de las sentencias se produjeron fuera del plazo establecido por la Corte; no se especifica si se ha impartido ningún curso de derechos humanos para las Fuerzas Armadas; y, lo más grave, no se ha realizado ninguna acción en el sentido de identificar, procesar y sancionar penalmente a los responsables por las violaciones de los derechos humanos).

En los últimos años, ha desarrollado un trabajo notable la Comisión de Amnistía del Ministerio de Justicia de Brasil. Es un órgano del Estado brasileño vinculado al Ministerio de Justicia y compuesto por 24 consejeros, en su mayoría agentes de la sociedad civil o profesores universitarios, uno de los cuales es designado por las víctimas y otro por el Ministerio de Defensa. Creada hace diez años, en el 2001, con el objetivo de reparar moral y económicamente a las víctimas de los excesos, actos arbitrarios y violaciones de derechos humanos cometidos entre 1946 y 1988, la Comisión cuenta hoy con más de setenta mil peticiones de amnistía registradas. Hasta el 2011 había declarado "amnistiadas políticas" a más de 35 mil personas y promovido el pedido oficial de disculpas del Estado por las violaciones cometidas. En aproximadamente 15 mil de estos casos, la Comisión reconoció igualmente el derecho a reparación económica. El acervo de la Comisión de Amnistía es el más completo fondo documental sobre la dictadura brasileña $(1964-1985)^{30}$.

En cuanto a Colombia, la guerra entre las FARC y el Estado de Colombia ha durado 52 años y arroja un saldo de aproximadamente ocho millones de víctimas, 220.000 muertos, 45.000 desaparecidos y desplazados. Los diálogos de La Habana entre delegados del Gobierno Nacional, presidido por el Presidente Juan Manuel Santos y delegados de las Fuerzas Armadas Revolucionarias de Colombia-Ejército del Pueblo, también conocidos como "proceso de paz en Colombia", con la decisión mutua de poner fin al conflicto armado nacional han dado como resultado un documento de casi trescientas páginas: el Acuerdo final para la terminación del conflicto y la

1/Escrito\%2014\%20de\%20dezembro\%20de\%202011.pdf.> (Acceso el 21-9-2014).

${ }^{29}$ Algunas de las estipulaciones de la Sentencia de la Corte Intreramericana sí se habían llevado a cabo: la aprobación por el Congreso Nacional de la Convención Interamericana sobre Desaparición Forzada de Personas. También cabe destacar la promulgación de la Ley n 12.527/2011 que regula el acceso a las informaciones públicas y la Ley n 12.528/2011 que creó la Comisión de la Verdad.

${ }^{30}$ GONZÁLEZ, E. y HOWARD, V. (Editores) En busca de la verdad. Elementos para la creación de una comisión de la verdad eficaz, cit., p.3. 
construcción de una paz estable y duradera, de 24 de agosto de $2016 .{ }^{31}$ Este Acuerdo se ha sometido a referéndum de los ciudadanos colombianos, el pasado día 2 de octubre, y ha sido rechazado. ${ }^{32}$ El expresidente Álvaro Uribe, máximo abanderado del no, el mismo que consiguió unir a casi todo el país en torno a la política de Seguridad Democrática que debilitó las FARC señalaba: "La paz es ilusionante, los textos de La Habana son decepcionantes". La posibilidad de participar en política de los líderes guerrilleros y el hecho de que ninguno pagará cárcel siempre y cuando reconozca sus crímenes ha sido la piedra angular de su campaña.

En el Preámbulo de este Acuerdo, se hace referencia a los puntos principales sobre los que versa el Acuerdo: El Punto 1 contiene el acuerdo "Reforma Rural Integral"; El Punto 1 contiene el acuerdo "Reforma Rural Integral"; El Punto 3 contiene el acuerdo "Cese al Fuego y de Hostilidades Bilateral y Definitivo y la Dejación de las Armas"; El Punto 3 también incluye el acuerdo sobre "Garantías de seguridad y lucha contra las organizaciones criminales responsables de homicidios y masacres o que atentan contra defensores y defensoras de derechos humanos, movimientos sociales o movimientos políticos, incluyendo las organizaciones criminales que hayan sido denominadas como sucesoras del paramilitarismo y sus redes de apoyo, y la persecución de las conductas criminales que amenacen la implementación de los acuerdos y la construcción de la paz". El Punto 4 contiene el acuerdo "Solución al Problema de las Drogas Ilícitas". Y el Punto 5 contiene el acuerdo "Víctimas",33 que es el que nos interesa ahora. En el mismo se establece que: "Desde el Encuentro Exploratorio de 2012, acordamos que el resarcimiento de las víctimas debería estar en el centro de cualquier acuerdo. El acuerdo crea el Sistema Integral de Verdad, Justicia, Reparación y No Repetición, que contribuye a la lucha contra la impunidad combinando mecanismos judiciales que permiten la investigación y sanción de las graves violaciones a los derechos humanos y las graves infracciones al Derecho Internacional Humanitario, con mecanismos extrajudiciales complementarios que contribuyan al esclarecimiento de la verdad de lo ocurrido, la búsqueda de los seres queridos desaparecidos y la reparación del daño causado a personas, a colectivos y a territorios enteros. El Sistema Integral está compuesto por la Comisión para el Esclarecimiento de la Verdad, la Convivencia y la No Repetición; la Unidad Especial para la Búsqueda de Personas dadas por desaparecidas en el contexto y en razón del conflicto armado; la Jurisdicción Especial para la Paz; las Medidas de reparación integral para la construcción de la paz; y las Garantías de No Repetición (Acuerdo, p.6).

\footnotetext{
${ }^{31}$ Acuerdo final para la terminación del conflicto y la construcción de una paz estable y duradera, de 24 de agosto de 2016. Disponible en: https://www.mesadeconversaciones.com.co/.../24_08_2016acuerdofinalfinalfinal-14720. Acceso el 08.10.2016. 32 El 'no' ha ganado con el 50,21\% al 'si' impulsado por el Gobierno de Juan Manuel Santos, que ya ha reconocido la derrota. La abstención ha alcanzado el 62,57\%, lo que supone que solo 13 millones de colombianos con derecho a voto acudieron a las urnas. "Colombia rechaza en referéndum el acuerdo de paz con las FARC" en eldiarioes (03/10/2016). Disponible en: http://www.eldiario.es/internacional/Colombia-rechaza-referendum-acu (Acceso el 08.10.2016).

33 Punto 5. Acuerdo sobre las Víctimas del Conflicto: "Sistema Integral de Verdad, Justicia, Reparación y No Repetición", incluyendo la Jurisdicción Especial para la Paz; y Compromiso sobre Derechos Humanos” (pp. 112-170).
} 
Es decir:

Sobre la base de estos principios llegamos a acuerdos centrales sobre: 1 . Sistema Integral de Verdad, Justicia, Reparación y No Repetición; y 2. Compromiso con la promoción, el respeto y la garantía de los derechos humanos. Dentro de estos compromisos se incluyen trascendentales acuerdos como la creación de la Comisión para el Esclarecimiento de la Verdad, la Convivencia y la No Repetición; la Unidad Especial para la Búsqueda de Personas dadas por Desaparecidas en el contexto y en razón del conflicto; la Jurisdicción Especial para la y las medidas específicas de reparación. Todos estos componentes se han articulado dentro de un Sistema Integral de Verdad, Justicia, Reparación y No Repetición (p.113)

Se cita como base la justicia y se argumenta que para luchar contra la impunidad se combinarán actuaciones de una Jurisdicción Especial para la Paz con mecanismos extrajudiciales complementarios. La alusión a la justicia hace preguntarse, a qué tipo de justicia se están refiriendo (retributiva, reparativa, transicional). Y la creación de una Jurisdicción Especial para la $\mathrm{Paz}^{34}$ ha transmitido la sensación de un Tribunal que juzgaría muy livianamente los cruentos delitos cometidos.

Entendemos que una respuesta amplia y genuina a los derechos de las víctimas -en el marco de la implementación de todos los demás acuerdos, que también garantizan derechos- es la base de la justicia. Para cumplir con este propósito y avanzar en la lucha contra la impunidad, el Sistema Integral combina mecanismos judiciales que permiten la investigación y sanción de las graves violaciones a los derechos humanos y las graves infracciones al Derecho Internacional Humanitario, en los términos que establece la Jurisdicción Especial para la Paz, con mecanismos extrajudiciales complementarios que contribuyan al esclarecimiento de la verdad de lo ocurrido, la búsqueda de los seres queridos desaparecidos y la reparación del daño causado a personas, a colectivos y a territorios enteros (Acuerdo sobre las Víctimas del Conflicto, p. 115).

Como principales objetivos de las medidas y mecanismos del Sistema Integral se establecen, entre otros:

i) Satisfacción de los derechos de las víctimas, mediante la combinación de mecanismos de carácter judicial y extra-judicial; ii) Rendición de cuentas, mediante el establecimiento de responsabilidades, todos los participantes en el conflicto, de forma directa o indirecta, combatientes o no combatientes, deberán asumir su responsabilidad por las graves violaciones e infracciones cometidas en el contexto y en razón del conflicto armado.

El Sistema Integral está compuesto por cinco mecanismos y medidas: i) Comisión para el Esclarecimiento de la Verdad, la Convivencia y la No Repetición: Será un órgano temporal y de carácter extrajudicial, que busca conocer la Verdad de lo ocurrido y contribuir al esclarecimiento de las violaciones e infracciones y ofrecer una explicación amplia a toda la sociedad de la complejidad del conflicto; promover el reconocimiento de las víctimas y de las responsabilidades de quienes participaron directa e indirectamente en el

\footnotetext{
${ }^{34}$ Jurisdicción Especial para la Paz: Estará constituida por una serie de salas de justicia, entre las que se incluye una Sala de Amnistía e Indulto, y un Tribunal para la Paz, para administrar justicia e investigar, esclarecer, perseguir y sancionar las graves violaciones a los derechos humanos y las graves infracciones al Derecho Internacional Humanitario. En "Los principios básicos del componente de justicia del sistema integral de verdad, justicia, reparación y no repetición (SIVJRNR)” se señala que los objetivos del componente de justicia del Sistema Integral de Verdad, Justicia, Reparación y No Repetición -en adelante el SIVJRNR- son satisfacer el derecho de las víctimas a la justicia, ofrecer verdad a la sociedad colombiana, proteger los derechos de las víctimas y contribuir al logro de una paz estable. Es decir, justicia, verdad, paz son las claves del componente del sistema de Justicia especial. (Acuerdo, p.130), completadas con medidas de reparación y restauración.
} 
conflicto armado; y promover la convivencia en los territorios para garantizar la no repetición; ${ }^{35}$ ii) Unidad especial para la búsqueda de personas dadas por desaparecidas en el contexto y en razón del conflicto armado; iii) Jurisdicción Especial para la Paz: Estará constituida por una serie de salas de justicia, entre las que se incluye una Sala de Amnistía e Indulto, y un Tribunal para la Paz, para administrar justicia e investigar, esclarecer, perseguir y sancionar las graves violaciones a los derechos humanos y las graves infracciones al Derecho Internacional Humanitario; iv) Medidas de reparación integral para la construcción de la paz: Se trata de medidas que buscan asegurar la reparación integral de las víctimas, incluyendo los derechos a la restitución, la indemnización, la rehabilitación, la satisfacción y la no repetición; y la reparación colectiva de los territorios, las poblaciones y los colectivos más afectados por el conflicto y más vulnerables, en el marco de la implementación de los demás acuerdos. Con este fin, se fortalecerán los mecanismos existentes, se adoptarán nuevas medidas, y se promoverá el compromiso de todos con la reparación del daño causado; v) Garantías de No Repetición (Acuerdo, p.117).

Sin embargo, también planea la sombra de si la amnistía y el indulto, (GUTIÉRREZ URRESTY, 2006) que están presentes en este Acuerdo, no se convertirá después en regla general:

"la terminación de las hostilidades la amnistía para los rebeldes únicamente estará condicionada a la finalización de la rebelión de las respectivas organizaciones armadas y al cumplimiento de lo establecido en el Acuerdo Final, sin perjuicio de lo dispuesto en los puntos 23 y 27. La finalización de la rebelión a efecto de acceder a la amnistía o indulto, se definirá en el Acuerdo Final. En los demás casos no amnistiables ni indultables, para la definición de la situación" (Acuerdo, p.131).

Se establece que las sanciones "tendrán como finalidad esencial satisfacer los derechos de las víctimas y consolidar la paz. Deberán tener la mayor función restaurativa y reparadora del daño causado, siempre en relación con el grado de reconocimiento de verdad y responsabilidad que se haga ante el componente de Justicia del SIVJRNR mediante declaraciones individuales o colectivas.". ${ }^{36}$ (Acuerdo, p.147). Y se completa con referencia a redenciones:

\begin{abstract}
"Las sanciones ordinarias que se impondrán cuando no exista reconocimiento de verdad y responsabilidad, cumplirán las funciones previstas en las normas penales, sin perjuicio de que se obtengan redenciones en la privación de libertad, siempre y cuando el condenado se comprometa a contribuir con su resocialización a través del trabajo, capacitación o estudio durante el tiempo que permanezca privado de libertad. En todo caso la privación efectiva de libertad no será inferior a 15 años ni superior a 20 en el caso de conductas muy graves." (Acuerdo, p.147).
\end{abstract}

\footnotetext{
${ }^{35}$ Mecanismo extra-judicial: La Comisión será un mecanismo extra-judicial. En este sentido, sus actividades no tendrán carácter judicial, ni podrán implicar la imputación penal de quienes

comparezcan ante ella. La información que reciba o produzca la Comisión no podrá ser trasladada por esta a autoridades judiciales para ser utilizada con el fin de atribuir responsabilidades en procesos judiciales o para tener valor probatorio; ni las autoridades judiciales podrán requerírsela. (Acuerdo, p.121).

${ }^{36}$ Las sanciones que se contemplan son de tres clases: I.- Sanciones aplicables a quienes reconozcan verdad exhaustiva, detallada y plena en la Sala de reconocimiento de verdad y responsabilidades; II.- Sanciones aplicables a quienes reconozcan Verdad y responsabilidades por primera vez en el proceso contradictorio ante la Sección de Primera Instancia del Tribunal para la Paz, antes de dictarse sentencia; III.- Sanciones aplicables a quienes no reconozcan Verdad y responsabilidad en el proceso contradictorio ante la Sección de Primera Instancia del Tribunal para la Paz y resulten declarados culpables por éste.
} 
Como actos de reparación "Medidas de reparación integral para la construcción de paz" se contemplan varias posibilidades: 1) Actos tempranos de reconocimiento de responsabilidad colectiva: "el Gobierno Nacional apoyará la realización, lo antes posible, luego de la firma del Acuerdo Final, de actos de reconocimiento y de contrición en los cuales el Gobierno, las FARC-EP y diferentes sectores de la sociedad que puedan haber tenido alguna responsabilidad en el conflicto, reconozcan su responsabilidad colectiva por el daño causado y pidan perdón, asumiendo cada uno lo que le corresponde, como expresión de voluntad de contribuir a un definitivo Nunca Más”; 2). Acciones concretas de contribución a la reparación: todos quienes hayan causado daños con ocasión del conflicto deben contribuir a repararlos. Esa contribución a la reparación será tenida en cuenta para recibir cualquier tratamiento especial en materia de justicia; 3i) Reparación colectiva en el fin del conflicto (Acuerdo, pp.158-159).

Tras la derrota en el referéndum se han iniciado inmediatamente conversaciones entre el actual Presidente Santos -que acaba de ser galardonado con el premio Nobel de la Paz, precisamente por las negociaciones con las FARC-y el expresidente, Uribe -defensor del no al Acuerdo- para revisar los puntos más polémicos. $^{37}$

La lectura que cabría hacer de este resultado podría ser la de que en la pugna entre la prioridad de las demandas de paz y reconciliación frente a las exigencias de justicia, verdad y reparación, ha primado la segunda sorprendentemente, las comunidades más castigadas por las FARC han votado a favor del Acuerdo y los sectores urbanos, en contra-. Suelen ser frecuentes las tensiones entre quienes desean olvidar el pasado y llevar a cabo una rápida transición que no suponga un costo moral, político, económico y aquéllos otros que consideran que una sociedad no puede reconciliarse sin altas dosis de justicia, exigiendo unas reformas estructurales en las instituciones y en las políticas para que, efectivamente, la no repetición, el nunca más pueda ser una realidad y se alcance la paz estable. (CORTÉS RODAS, 2006, p.85)

Es decir, por un lado están los ciudadanos que exigen una justicia retributiva o punitiva, que exigen un casto castigo a quienes han cometido crímenes y violaciones de derechos humanos. Por otro lado, están los defensores de una política del perdón, centrados en la urgencia de las necesidades de la paz. El primer modelo es el que se impuso en el cono sur de Latinoamérica, y también en Guatemala y El Salvador, dando primacía a las demandas de paz frente a las exigencias de justicia retributiva o correctiva -por las que se intentaba castigar a los

\footnotetext{
${ }^{37}$ Entre los que cabe citar: 1. Que los guerrilleros que cometieron crímenes graves paguen penas de prisión: se ha aceptado que los guerrilleros rasos, que son la gran mayoría, no sean llevados a la cárcel. Sin embargo, se considera que conceder total impunidad a los responsables de atrocidades es mal ejemplo que promovería nuevas violencias. Resulta difícil creer que van a aceptar abandonar las armas para ir a la cárcel; 2. Cuestionamientos a la Jurisdicción Especial para la Paz: La JEP es el mecanismo de justicia transicional dispuesto por el acuerdo de La Habana para juzgar los crímenes cometidos en el marco del conflicto por todos los actores. Los tribunales de la JEP sustituiría las facultades de revisión de todo lo actuado por la Contraloría, Procuraduría, Fiscalía, las cortes, Comisión de Acusaciones y la Justicia Penal Militar. Ciertamente es muy remota la posibilidad de que las partes abandonen la JEP por la justicia ordinaria; 3. Restringir la elegibilidad política de los guerrilleros; 4. Narcotráfico; 5. Límites a la reforma rural.
} vol.10, n. 01, Rio de Janeiro, 2017.pp.333-364 356 
criminales-. El modelo de justicia retributiva sólo es posible cuando se suprime la "justicia del Estado vencedor", como sucedió en Alemania al acabar la Segunda guerra mundial, y en la ex Yugoslavia y en Ruanda, cuando se constituyeron los tribunales de La Haya y Arusha. (CORTÉS RODAS, 2006, p.86)

En Brasil, Sudáfrica, Guatemala y El Salvador, por el contrario, los procesos de transición de la dictadura a la democracia, o de guerras civiles a la paz, no fueron el resultado de un triunfo militar de las fuerzas que luchaban por la democracia contra sus enemigos. Triunfó la política del "perdón y el olvido" acompañada de numerosas amnistías a muchos de quienes habían violado derechos humanos sobre la justicia retributiva que demandaba que se juzgara a todos los militares y civiles que habían participado en esos terribles delitos. Mientras que en Nüremberg, en La Haya y en Arusha se impuso la justicia retributiva, en el cono sur latinoamericano primaron las necesidades de paz sobre las exigencias de castigo por las violaciones de derechos humanos (CORTÉS RODAS, 2006, p.87).

Posiblemente, en el modelo de transición colombiano de la guerra a la paz, ha pesado más la opinión que este proceso de paz no debe llevarse a cabo desde una perspectiva que haga primar la paz sobre la justicia, sino que deba desarrollarse "articulando una política de justicia retributiva, con una política de perdón" (CORTÉS RODAS, 2006, p.90).

\section{REFLEXIONES FINALES}

De lo expuesto, cabe destacar dos reflexiones principales. La primera reflexión es que se aprecia una clara dialéctica entre justicia transicional y paz. La cuestión es si puede justificarse un castigo penal reducido para alcanzar la paz. El discurso manipulador de la justicia transicional esconde un objetivo de impunidad para los victimarios. Por el contrario, el discurso emancipador y democrático de la justicia transicional pretende luchar contra la impunidad. Los derechos de las víctimas a la verdad, a la memoria y a la reparación son los instrumentos de los que se nutre. Con todo, no puede ignorarse que hay una tensión entre justicia y paz en la medida en que, si hay que optar por cierto grado de impunidad de los victimarios para conseguir la paz (amnistía u otras formas), tal decisión comporta un menoscabo de la justicia. A la inversa, la imposición de la justicia retributiva y la protección de los derechos de las víctimas pueden ser consideradas como obstáculos para la paz. Uprimny ya ha advertido esta dificultad, especialmente en el marco de un proceso transicional basado en negociaciones de paz cuando ha habido actores armados, de manera que, "así como la impunidad resulta una opción imposible, desde el punto de vista ético y jurídico, la posibilidad de una justicia retributiva plena parece también quedar excluida" (UPRIMNY, 2006b, p. 20).

El reto consiste en cómo combinar adecuadamente, en un proceso de transición, tanto las exigencias de justicia retributiva con "dosis sustanciales de perdón" (UPRIMNY, 2006b, p. 20). No hay una fórmula para que 
los diversos valores y principios en conflicto puedan ajustarse sin tensiones. Es una dialéctica de cesiones y negociaciones. Por ello, cada sociedad democrática deberá diseñar su propia fórmula de justicia transicional, en función de la de gravedad de los hechos y delitos acaecidos, del grado de violación de los derechos humanos, de las circunstancias políticas, del grado de solidez del sistema constitucional y democrático que tenga el país. No hay soluciones uniformes e idénticas para todos los casos. La justicia transicional recupera el espíritu de la clásica definición de la justicia de "dar a cada uno lo suyo" para establecer arbitrar los procedimientos que, en cada caso, resulten más oportunos.

La justicia transicional, sin perder la perspectiva del pasado, tiene sus miras puestas en el futuro. Pero hay que estar atentos a que bajo el ropaje de la justicia transicional no se esconda un discurso meramente retórico que en lugar de ofrecer justicia y legalidad se ampare una solución meramente política de cierre de un ciclo que pretenda construir la legalidad de nuestro presente, aunque sea democrático, sobre el olvido de tantas injusticias. Es decir, tanto el rol discursivo como el rol normativo de la justicia transicional son dos posibilidades para llevar a efecto una negociación de paz. También hay que estar atentos al peligro que puede encerrar el derecho a la memoria histórica de forma que no solo acabe sin solucionar problemas sino que contribuya a abrir heridas.

La dialéctica de justicia transicional se acaba resumiendo en dos ideas básicas: "i) el acuerdo para llegar a "un equilibrio entre paz y justicia y, ii) el reconocimiento del carácter normativo y de la aplicabilidad de los derechos de las víctimas a la verdad, la justicia y la reparación" (UPRIMNY; SAFFON, 2008, p. 174). Sin embargo, no puede ignorarse que hay una tensión entre justicia y paz, en la medida en que, si hay que optar por cierto grado de impunidad de los victimarios para conseguir la paz, tal decisión comporta un menoscabo de la justicia. A la inversa, la imposición de la justicia retributiva y la protección de los derechos de las víctimas pueden ser consideradas como obstáculos para la paz. El Derecho -y la justicia- son piezas esenciales para conseguir una paz efectiva y duradera (GARRIDO, 2011, p.34). (BALLESTEROS LLOMPART, 2004).

La segunda reflexión es que los procesos de justicia transicional no pueden comprenderse en sus debidos términos si la justicia no se configura como el pilar básico en el que se asienta todo el proceso para, a partir de ahí, aplicar las exigencias de un sistema democrático. Esos procesos de transición democrática que se han desarrollado en algunos países entrañan un complejo conjunto de dilemas morales, políticos y jurídicos, a los que esas sociedades deben hacer frente. Los delitos a los que se aplica la justicia transicional son especialmente graves (asesinatos, violaciones, torturas, desapariciones). Hay que evitar la sensación de impunidad de los victimarios, porque sería una llamada a que se repitan delitos y gravísimas violaciones de derechos humanos. En la justicia transicional no puede desterrarse la justicia retributiva. Entendemos que se trata de una justicia mixta retributivarestaurativa la que está presente en la justicia transicional, donde se prefiere la reparación del daño causado antes que su represión, pero sin olvidar el mínimum de castigo para este tipo de delitos tan deleznables. La suavidad y el rigor atenuado de la punición que acompaña a la justicia restaurativa tienen una aplicación más difícil en procesos vol.10, nº. 01, Rio de Janeiro, 2017.pp. 333-364 
de justicia transicional, aunque no imposible (baste recordar las numerosas leyes de amnistía presentes en este tipo de procesos). Pero ello no implica sustituir la justicia retributiva por la justicia restaurativa totalmente. Ambos paradigmas de justicia son imprescindibles en la justicia transicional. Garantizar el derecho a la justicia, a la verdad y a la reparación se convierte en los ejes de ese proceso de transición.

La justicia transicional no constituye una tipología de justicia que se pueda encuadrar de forma simplista en la Teoría de la justicia. Es una realidad compleja y más que un tipo de justicia, se trata de un movimiento que intenta hacer justicia. Y lo hace adaptándose a sociedades que se transforman a sí mismas después de un período de violación generalizada de los derechos humanos. La incidencia del marco estatal en el que se desarrolle y las circunstancias políticas, así como también las económicas, son condicionantes que marcan tanto la posibilidad de iniciar un proceso de justicia transicional, como la viabilidad y éxito del mismo.

El reto estriba en cómo articular los diversos mecanismos y procesos, que resulten más idóneos, según los distintos contextos, en aras de la consecución de una plena justicia transicional. La construcción de estos procesos es responsabilidad de muchos agentes (políticos, juristas, organizaciones civiles, víctimas y victimarios, politólogos) y hay muchos intereses subyacentes. Con las adecuadas dosis de realismo y pragmatismo (el idealismo y las meras buenas intenciones pueden dar al traste con muchos de los acuerdos que se van consiguiendo) hay que seguir trabajando para lograr unos resultados que hagan posible una convivencia pacífica de futuro.

\title{
TRANSITIONAL JUSTICE: THE RENOUNCE OF THE CAN NOT GIVE?
}

\begin{abstract}
Transitional justice is not usually enjoy acceptance by victims of systematic human rights violations because they tend to assimilate or impunity symbolic penalties by the perpetrators. Therefore, they resist giving up what indispensable, as is justice. The right to full compensation implies that judgments are exercised with democratic control and that no one is above the law. In this peace processes are transparent and democratic control. In this study the concept, phases and principles of transitional justice will be analyzed. Such approaches allow to reread the various processes of transitional justice. special attention to the peace process in Brazil and the analysis of the peace agreement in Colombia which has just being rejected by Colombian citizens in referendum will be provided. This work aims to answer the challenge of finding a balance between the right to the truth (history memory, with the right to know about those killed or made to disappear accordingly) and forgiveness and reconciliation. The right to justice stands with the cornerstone of these processes. There can not be peace if justice is sacrificed.
\end{abstract}

Keywords: Transitional Justice; Memory; Forgetting; Forgiveness; Reconciliation. 


\section{REFERENCIAS BIBLIOGRÁFICAS}

AA.VV. "Qué es la justicia transicional". Centro Internacional para la Justicia Transicional. https://www.ictj.org/sites/default/files/ICTJ-Global-Transitional-Justice-2009-Spanish.pdf (Acceso el 15.02.2015).

ARCOS RAMÍREZ, F. ¿Guerras en defensa de los derechos humanos?. Problemas de legitimidad en las intervenciones humanitarias, Madrid: Dykinson, 2002.

ARDILA, D. Justicia transicional: principios básicos. escolapau.uab.cat/img/programas/derecho/justicia/doc004.pdf(Acceso el 07.10.2016).

BALLESTEROS LLOMPART, J., "Ripensare la pace, contro la cultura del terrore e della manipolazione”. Ragion pratica, no22 2004, pp. 161-178.

BENJAMIN, W. Tesis sobre la historia y otros Fragmentos. México: Contrahistorias, 2005.

BERINSTAIN, A., La pena-retribución y las actuales concepciones criminológicas, Buenos Aires: Depalma, Criminología contemporánea, 1982.

BOTERO, C. "Estándares Internacionales y procesos de transición en Colombia” en Entre el perdón y el paredón: preguntas y dilemas de la justicia transicional. Bogotá: Uniandes, 2000.

CORTÉS RODAS, F. "Entre el perdón y la justicia. Reflexiones en torno a los límites y contradicciones de la justicia transicional” en Camila de Gamboa Tapias (Ed.), Justicia Transicional: teoría y praxis, Bogotá: Universidad del Rosario, 2006, pp.85-112. Disponible en https://books.google.es/books?isbn=9588298113*. (Acceso el 08.10.206).

CUYA, E. MENSCHENRECHTSZENTRUM, N. Las Comisiones de la Verdad en América Latina, 1996 Disponible en <www.derechos.org/koaga/iii/1/cuya.html. Acceso el 22.08.2014.

ELSTER, J. Rendición de cuentas. La justicia transicional en perspectiva, Buenos Aires: Katz, 2006.

DALY, K, Y IMMARIGEON, R., “The Past, Present, and Future of Restaurative Justice: some critical reflection” en Contemporary Justice Review, 1 (1999).

FALCÓN Y TELLA, Maj., La justicia como mérito, Madrid: Marcial Pons, 2014.

FORCADELL ALVAREZ, C; CARRERAS ARES, J. J. Usos públicos de la historia. Universidad de Zaragoza, Prensas Universitarias de Zaragoza: Marcial Pons, 2013.

GARAPON, A. "Justicia transicional y justicia reconstitutiva”, en Cuadernos Electrónicos de Filosofía del Derecho, no29, Valencia, 2014, p.24). [Disponible en <http://ojs.uv.es/index.php/CEFD/article/view/3836>]. (Acceso el 20.08.2014).

GARRIDO GÓMEZ, MaI."La construcción del derecho a la paz” en Garrido Gómez, Må. (Editora) El derecho a la paz como derecho emergente, Barcelona: Atelier, 2011. 
GIMÉNEZ-SALINAS COLOMER, E., "La mediación en el sistema de justicia juvenil: una visión desde el Derecho comparado", Cuadernos del IV Crim., n¹0, 1996.

GONZÁLEZ, E. Y HOWARD, V. (Editores) En busca de la verdad. Elementos para la creación de una comisión de la verdad eficaz, Brasilia: Comisión de Amnistía del Ministerio de Justicia de Brasil; Nueva York: Centro Internacional para la Justicia Transicional, 2013. (Disponible en < http://ictj.org/sites/default/files/ICTJ-BookTruth-Seeking-2013-Spanish.pdf>). (Acceso el 10.02.2016).

GORDILLO SANTANA, L.F., La justicia restaurativa y la mediación penal, Madrid, Iustel, 2007.

GORCZEVSKI, C; COSTODIO LIMA, W. "Análisis das Políticas Públicas decorrentes da condenação do Brasil na Corte Interamericana nos casos Ximenes Lopes e. Garibaldi” en XI Seminario Nacional Demadas Sociais e Políticas Públicas na Sociedade Contemporánea, UNISC. Disponible en. https://online.unisc.br/acadnet/anais/index.php/snpp/.../2763.

GUTIÉRREZ URRESTY, A.M. "Las amnistías e indultos, un hábito social en Colombia” en Camila de Gamboa Tapias (Ed.), Justicia Transicional: teoría y praxis, Bogotá: Universidad del Rosario, 2006, pp.388-408. [Disponible en https://books.google.es/books?isbn=9588298113*. (Acceso el 08.10.206).

JARAMILLO, J; DELGADO, M. "Deber de memoria" y "razones de olvido" en la justicia transicional colombiana. Análisis Político, 71, 2011, pp. 129-147. Disponible en: http://www.bdigital.unal.edu.co/39392/1/44243-208322-1-SM.pdf. (Acceso el 02.11.2015).

KRISTEVA, J. Semiotiké Recherches pour une semanalyse. Paris, Du Seuil, Col Tel Quel, 1969 (Traducción al español: Semiótica Iy II. Madrid: Fundamentos, 1981).

LEFRANC, S., "Políticas del perdón", en Desarrollo Económico 45, 178 (2005) pp. 163-186. [Disponible en $<$ halshs.archives-ouvertes.fr/view_by_stamp.php?\&>]. (Acceso el 21.08.2014).

LEME FRANCO, T. Efetividade das decisões proferidas pela Corte interamericana de Direitos Humanos: identificação dos marcos teóricos e análise da conduta do Estado brasileiro (Disertación). [Disponible en <http://2ccr.pgr.mpf.mp.br/coordenacao/grupos-de-trabalho/justica-de-transicao/relatorios 1/Escrito\%2014\%20de\%20dezembro\%20de\%20201 1.pdf.)]. (Acceso el 21-9-2014).

LESSA, F., Memory and Transitional Justice in Argentina and Uruguay. Against Impunity, Nueva York : Palgrave Macmillan, 2013.

NARVÁEZ, L. "Memoria y democracia". Disponible en < fundacionparalareconciliacion.org/.../docu527ab8edf0a70_06112013_2.> (Acceso el 20.08.2014).

PÁRAMO ARGÜELLES, J.R de, “Argumentación y negociación en los procesos de transición política”, en La justicia de transición: concepto, instrumentos y experiencias, Editorial Universidad del Rosario (Colombia), 2013, pp. 3-25.

PASCUAL RODRÍGUEZ, E. (Coordinadora), Los ojos del otro. Encuentros restaurativos entre víctimas y ex miembros de la organización terrorista ETA. Madrid: Sal Terrae, 2013.

PÉREZ TRIVIÑO, J. L. Los juicios de Nuremberg. Barcelona: UOC, 2007. 
PITTAVINO, R. et Al. Las caras ocultas que sólo se ven en el recuerdo. Institución de Formación Docente "Dr. Miguel Puíggari”. [Disponible en http://www.ses.me.gov.ar/a30delgolpe/home/pdf/movilizacion/06lascarasocultas.pdf]. (Acceso el 1-11-2015).

RADZIK, L., De la enmienda a la reconciliación. La expiación en la moral, el derecho y la política. Trad. Sergi Rosell, Madrid: Avarigani Editores, 2015.

REYES MATE, M. Justicia de las víctimas. Terrorismo, memoria, reconciliación. Barcelona: Anthropos, 2008.

RICOEUR, P. La memoria, la historia, el olvido. Buenos Aires: FCE, 2004.

RIEFF, D. Contra la memoria. Madrid:Debate, 2012.

RINCÓN, T. Verdad, justicia y reparación. La justicia de la justicia transicional. Bogotá: Universidad del Rosario, 2010.

RODRÍGUEZ MONTENEGRO, G.P. "Los límites del perdón. Notas sobre la justicia transicional en Sudáfrica, Centroamérica y Colombia” en Justicia Juris, vol. 7, n² 2. Julio-Diciembre 2011, pp.52-66.

RODRÍGUEZ PEÑA, J.I. El perdón y la filosofía. Tesis de Maestría en Filosofía. Repositorio Institucional de la Universidad de Rosario (http://hdl.handle.net/10336/4329). [Disponible en <repository.urosario.edu.co>] (Acceso el 25.08.2014).

ROMERA ANTÓN, C., "El proceso de mediación en el ámbito penal" en VAZQUEZ DE CASTRO, E. (Director), Practicum Mediación, 2014. Navarra: Thomson Reuters Aranzadi, 2013, pp.381-414.

ROSA, A. "Recordar, describir y explicar el pasado, ¿qué, cómo y para el futuro de quién?" en Carretero, M., Sosa, A. \& González, M. F. (comp.) Enseñanza de la historia y memoria colectiva. Buenos Aires: Paidós, 2013.

SARAVIA MÉNDEZ, G., "La memoria en el espacio público, la memoria como derecho". Papeles el Tiempo de los Derechos, Madrid: Instituto de Derechos Humanos Bartolomé de las Casas, nº14, 2014.

SAUCA CANO, J.Ma. "El derecho ciudadano a la memoria histórica" en J. A. Martín Pallín y R. Escudero Alday (Eds.), Derecho y memoria histórica (104). Madrid: Trotta, 2008.

SOUSA SANTOS, B. (de). Si Dios fuese un activista de los derechos humanos, Trad, de C. Martín Ramírez, Madrid: Trotta, 2014.

TODOROV, S. Los abusos de la memoria, Barcelona,Paidós, 2000.

TORRALBA, F., Memoria histórica, reconciliación y postconflicto. II Congreso Edificar la Paz en el siglo XXI, Bogotá, septiembre 2014. Disponible en: <http://www.cartadelapaz.org/> (Acceso el 05.06.2015).

UPRIMNY YEPES, R. "Algunas herramientas conceptuales para el análisis del caso colombiano" en R. Uprimny Yepes y C. Botero, E. Restrepo, y Ma.P. Safon, justicia transicional sin transición? Verdad, justicia y reparación en Colombia. Bogotá: Centro de Estudios de Derecho, Justicia y Sociedad., 2006.

"Derecho a la verdad: alcances y límites de la verdad judicial" en Camila de Gamboa Tapias (Ed.), Justicia Transicional: teoría y praxis, Bogotá: Universidad del Rosario, 2006, pp.345-375. [Disponible en https://books.google.es/books?isbn=9588298113*. (Acceso el 08.10.206). 
UPRIMNY YEPES, R; SAFON, Ma.P., "Justicia transicional y Justicia restaurativa: Tensiones y complementariedades" en UPRIMNY YEPES, R. BOTERO, C. RESTREPO, E. y SAFON, Ma.P. jJusticia transicional sin transición? Verdad, justicia y reparación en Colombia, Bogotá: Centro de Estudios de Derecho, Justicia y Sociedad (DJS), 2006, pp.109-138. [Disponible en: http://www.minjusticia.gov.co/Portals/0/Foros\%20Justicia\%20Transicional/LIBRO\%20J.TRANS.pdf (Acceso el 26.08.2014).

UPRIMNY YEPES, R; SAFFON, M. "Justicia transicional y justicia restaurativa: tensiones y complementariedades", en Angélica Rettberg (Edit.) Entre el perdón y el paredón. Preguntas y Dilemas de la Justicia Transicional, Bogotá: Ediciones UNIANDES/ IDRC, 2005.

VALENCIA VILLA, H. Diccionario Derechos Humanos, Madrid:Espasa, 2003.

VALENCIA VILLA, H., "Introducción a la justicia transicional". Claves de razón práctica, nº. 180, Madrid, 2008, pp.76- 82. [Disponible en <http://escolapau.uab.es/img/programas/derecho/justicia/seminariojt/tex03.pdf> (Acceso el 18.03.2016).

VALCARCEL, A. La memoria y el perdón. Madrid: Herder Editorial, 2011.

WALZER, M. Reflexiones sobre la guerra. Barcelona: Ediciones Paidós, 2004.

WRIGHT, M., Justice for Victims and Offedenders: A Restorative Response to Crime, Winchester: Waterside Press, 2a ed., 1996.

\section{DOCUMENTOS, JURISPRUDENCIA}

Acuerdo final para la terminación del conflicto y la construcción de una paz estable y duradera, de 24 de agosto de 2016. Disponible en: https://www.mesadeconversaciones.com.co/.../24_08_2016acuerdofinalfinalfinal-14720. Acceso el 08.10.2016.

CENTRO INTERNACIONAL PARA LA JUSTICIA TRANSICIONAL (ICTJ, 2015). ¿Qué es la justicia transicional? [Disponible en <http://ictj.org/es/que-es-la-justicia-transicional>]. (Acceso el 2.11.2015).

"COLOMBIA RECHAZA EN REFERÉNDUM EL ACUERDO DE PAZ CON LAS FARC" en eldiario.es (03/10/2016). Disponible en: http://www.eldiario.es/internacional/Colombia-rechaza-referendum-acu (Acceso el 08.10.2016).

COMISIÓN INTERAMERICANA DE DERECHOS HUMANOS (CIDH). (1986). Informe Anual 1985 1986- OEA/Ser.L/V/II.68, Doc. 8 rev. 1, p. $205 . \quad$ [Disponible https://www.cidh.oas.org/annualrep/85.86span/Indice.htm]. (Acceso el 2.11.2015).

CIDH_CP-19/10 - Sentença do caso Gomes Lund e outros ("Guerrilha do Araguaia") Vs. Brasil- (sentencia de 24 de noviembre de 2010). La Sentencia puede consultarse en: <http://www.corteidh.or.cr/docs/casos/articulos/seriec_219_por.pdf.> (Acceso el 12-12- 2014).

Estatuto de Roma (documento A/CONF.183/9, de 17 de julio de 1998). <http://www.un.org/spanish/law/icc/statute/spanish/rome_statute\%28s\%29.pdf> (Acceso el 02-04-2015). 
FUNDACIÓN CARTA DE LA PAZ. Los resentimientos históricos. [Disponible en $<$ http://www.cartadelapaz.org/es/texto.php $>\quad<\quad$ http://www.cartadelapaz.org/portal/los-resentimientoshistoricos/>]. (Acceso el 21.08.2014).

Conceptos, raíces y lógica de los resentimientos. Plataforma de enlace a los institutos de la paz de la Universitas Albertiana. [Disponible en <http://www.cartadelapaz.org/ip/archivo/dos/dos_comentario.htm>]. (Acceso el 2.11.2015).

Fundación para la Reconciliación en Colombia [Disponible en <www.fundacionparalareconciliacion.org $>$ ]. (Acceso el 2.11.2015).

Sentença do caso Gomes Lund e outros ("Guerrilha do Araguaia") Vs. Brasil- (sentencia de 24 de noviembre de 2010). <http://www.corteidh.or.cr/docs/casos/articulos/seriec_219_por.pdf.> (Acceso el 12-12-2014).

Resolución 60/147, de 16 de diciembre de 2005, de Naciones Unidas. [Disponible en $<$ http://www.ohchr.org/SP/ProfessionalInterest/Pages/RemedyAndReparation.aspx.> (Acceso el 15.03.2016).

Trabalho enviado em 09 de outubro de 2016.

Aceito em 05 de janeiro de 2017. 